\title{
Coupled $\mathrm{Ge} / \mathrm{Si}$ and $\mathrm{Ge}$ isotope ratios as geochemical tracers of seafloor hydrothermal systems: Case studies at Loihi Seamount and East Pacific Rise $9^{\circ} 50^{\prime} \mathrm{N}$
}

\author{
Escoube Raphaelle ${ }^{1,2,3}$, Rouxel Olivier ${ }^{2,4, *}$, Edwards Katrina ${ }^{5}$, Glazer Brian ${ }^{6}$, Donard Olivier F.X. ${ }^{1}$ \\ ${ }^{1}$ LCABIE, U. Pau et Pays de l'Adour, CNRS UMR 525, Hélioparc, 64053 Pau, France \\ ${ }^{2}$ Université de Bretagne Occidentale, Institut Européen Universitaire de la Mer, Plouzané, France \\ ${ }^{3}$ Dept. of Earth Sciences, University of Oxford, Oxford, UK \\ ${ }^{4}$ IFREMER, Centre de Brest, Plouzané, France \\ ${ }^{5}$ University of Southern California, USA \\ ${ }^{6}$ Dept. of Oceanography, University of Hawaii, USA \\ *Corresponding author : Olivier Rouxel, email address : orouxel@ifremer.fr
}

\begin{abstract}
:
Germanium (Ge) and Silicon (Si) exhibit similar geochemical behaviour in marine environments but are variably enriched in seafloor hydrothermal fluids relative to seawater. In this study, Ge isotope and Ge/Si ratio systematics were investigated in low temperature hydrothermal vents from Loihi Seamount (Pacific Ocean, $18^{\circ} 54^{\prime} \mathrm{N}, 155^{\circ} 15^{\prime} \mathrm{W}$ ) and results were compared to high-temperature vents from the East Pacific Rise (EPR) at $9^{\circ} 50^{\prime} \mathrm{N}$. Loihi offers the opportunity to understand contrasting Ge and Si behaviour in low temperature seafloor hydrothermal systems characterized by abundant Fe oxyhydroxide deposition at the seafloor. The results show that both $\mathrm{Ge} / \mathrm{Si}$ and $\delta 74 / 70 \mathrm{Ge}$ in hydrothermal fluids are fractionated relative to the basaltic host rocks. The enrichment in $\mathrm{Ge}$ vs. Si relative to fresh basalts, together with $\mathrm{Ge}$ isotope fractionation $(\triangle 74 / 70 \mathrm{Ge}$ fluid-basalt up to $1.15 \%$ at EPR $9^{\circ} 50^{\prime} \mathrm{N}$ and $1.64 \%$ at Loihi) are best explained by the precipitation of minerals (e.g. quartz and Fe-sulfides) during higher temperature seawater-rock reactions in the subsurface. The study of Fe-rich hydrothermal deposits at Loihi, largely composed of Fe-oxyhydroxides, shows that Ge isotopes are also fractionated upon mineral precipitation at the seafloor. We obtained an average Ge isotope fractionation factor between Fe-oxyhydroxide (ferrihydrite) and dissolved $\mathrm{Ge}$ in the fluid of $-2.0 \pm 0.6 \%$ (2sd), and a maximum value of $-3.6 \pm 0.6 \%$ (2sd), which is consistent with recent theoretical and experimental studies. The study of a hydrothermal chimney at Bio 9 vent at EPR $9^{\circ} 50^{\prime} \mathrm{N}$ also demonstrates that $\mathrm{Ge}$ isotopes are fractionated by approximately $-5.6 \pm 0.6 \%$ (2sd) during precipitation of metal sulfides under hydrothermal conditions. Using combined $\mathrm{Ge} / \mathrm{Si}$ and estimated $\mathrm{Ge}$ isotope signatures of $\mathrm{Ge}$ sinks and sources in seawater, we propose a preliminary oceanic budget of Ge which reveals that an important sink, referred as the "missing Ge sink", may correspond to Ge sequestration into authigenic Fe-oxyhydroxides in marine sediments. This study shows that combining $\mathrm{Ge} / \mathrm{Si}$ and $\delta 74 / 70 \mathrm{Ge}$ systematics provides a useful tool to trace hydrothermal $\mathrm{Ge}$ and $\mathrm{Si}$ sources in marine environments and to understand formation processes of seafloor hydrothermal deposits.
\end{abstract}

Keywords : Germanium isotope, Silica, Seafloor hydrothermal systems, Sulfides, Fe- oxyhydroxide 


\section{$\underline{\text { 1. Introduction }}$}

Seafloor hydrothermal activity along mid-oceanic ridges is a fundamental process controlling global heat flux and chemical exchange between the oceanic crust and the oceans and provides a major source of dissolved silica to the ocean (e.g. Edmond et al., 1979; Stein and Stein, 1994; Elderfield and Schultz, 1996; Wheat et al., 2002; Wheat et al., 2004). Traditionally considered as a "pseudo-isotope' tracer for Silicon ( $\mathrm{Si}), \mathrm{Ge} / \mathrm{Si}$ ratios in seawater and marine diatoms have been previously used to quantify Si fluxes to the oceans (Froelich and Andreae, 1981; Froelich et al., 1985a; Froelich et al., 1985b; Mortlock and Froelich, 1986; Froelich et al., 1989). In particular, it has been suggested that Ge/Si ratio in seawater could help to evaluate the relative proportion of hydrothermal vs. riverine input of silica to the global ocean (Mortlock and Froelich, 1986; Murnane and Stallard, 1988, 1990; Froelich et al., 1992; Mortlock et al., 1993; Elderfield and Schultz, 1996). Modern seawater is characterized by homogeneous $\mathrm{Ge} / \mathrm{Si}$ ratios defined at about $0.7 \mu \mathrm{mol} / \mathrm{mol}$. In contrast, hydrothermal vent fluids are characterized by higher Ge/Si values between 8 and $14 \mu \mathrm{mol} / \mathrm{mol}$ (Mortlock et al., 1993; Elderfield and Schultz, 1996), which is also higher than the average oceanic crust value defined at $2.2 \mu \mathrm{mol} / \mathrm{mol}$ (De Argollo and Schilling, 1978; Bernstein, 1985; Rouxel et al., 2006). The relative enrichment of Ge vs. Si in seafloor hydrothermal fluid and geothermal water has been generally considered to result from mineral-fluid interactions at depth, including the precipitation of Ge-poor secondary minerals, such as quartz and smectite (Arnorsson, 1984; Mortlock et al., 1993; Pokrovski and Schott, 1998; Evans and Derry, 2002). Low temperature weathering reactions may also affect Ge/Si ratios, considering the high affinity of Ge for iron oxyhydroxides, organic compounds and clay minerals (Bernstein, 1985; Kurtz et al., 2002).

Recently, Ge isotope ratios $\left(\delta^{74 / 70} \mathrm{Ge}\right)$ have been used as new geochemical tracers of Ge sources and behaviour in marine and hydrothermal environments (Rouxel et al., 2006; Siebert et al., 2006; Qi et al., 2011; Siebert et al., 2011; Escoube et al., 2012; Belissont et al., 2014). Based on the Ge isotope composition of modern marine biogenic silica, it has been suggested that the Ge isotopic composition of the ocean is enriched in heavy isotopes relative to the oceanic crust, by up to $2.5 \%$ (Rouxel et al., 2006, Escoube et al, 2012). Although the driving mechanisms controlling $\mathrm{Ge}$ isotopes in seawater are still unknown, establishing a preliminary balance of the Ge isotope composition in seawater requires: (1) placing boundaries on the Ge isotope composition of dissolved Ge that enters the ocean, e.g., through seafloor hydrothermal systems, and (2) investigating the fractionation of Ge isotopes during 
Ge precipitation and sequestration, e.g., in clay, Fe-oxyhydroxides, and/or sulfides at the seafloor.

Here, we investigated hydrothermal vents from the Loihi Seamount (Pacific Ocean, $\left.18^{\circ} 54^{\prime} \mathrm{N}, 155^{\circ} 15^{\prime} \mathrm{W}\right)$ that are characterized by distinct chemistry with high $\mathrm{Fe}$ and $\mathrm{Si}$ concentrations and low sulfide concentration, leading to the formation of extensive Fe-rich microbial mats and hydrothermal deposits at the seafloor (e.g. Emerson and Moyer, 2002; Glazer and Rouxel, 2009). Hence, the Loihi Seamount hydrothermal field provides an ideal site in which to study Ge-isotope systematics during hydrothermal alteration of volcanic rocks and Ge precipitation in Fe-rich deposits. We also investigated Ge isotope signatures of a wellstudied high-temperature hydrothermal system from the East Pacific Rise (EPR) at 9 ${ }^{\circ} 50^{\prime} \mathrm{N}$ (e.g. Von Damm, 2004). The very young age of the lava flows along the axial summit trough of EPR at $9-10^{\circ} \mathrm{N}$ offers the opportunity to study Ge isotope systematics during the early stage of high-temperature hydrothermal venting and active formation of hydrothermal sulfide deposits.

The combined study of Ge/Si and Ge isotope ratios in both high- and low-temperature seafloor hydrothermal fluids and associated hydrothermal deposits allow a first estimate of the Ge isotope composition of the hydrothermal flux in the ocean and determine major processes affecting the fractionation of $\mathrm{Ge}$ isotopes between the oceanic crust and seawater. This approach is also required in order to apply Ge isotope chemistry as a useful paleooceanographic proxy in ancient marine sedimentary rocks.

\section{Geological Setting}

Loihi Seamount (Hawaii, $18^{\circ} 54^{\prime} \mathrm{N}, 155^{\circ} 15^{\prime} \mathrm{W}$ ) is the youngest submarine volcano in the Hawaiian-Emperor Chain, rising $\sim 4 \mathrm{~km}$ above the abyssal plain to a depth about 960 meters below sea level (mbsl) (Fig. 1). The vent fluids at Loihi are characterized as highly enriched in $\mathrm{Fe}, \mathrm{Mn}, \mathrm{Si}, \mathrm{CH}_{4}$ and $\mathrm{CO}_{2}$ (Karl et al., 1988; Sedwick et al., 1992; Wheat et al., 2000; Glazer and Rouxel, 2009). The high $\mathrm{CO}_{2}$ results in higher alkalinity and lower $\mathrm{pH}$ conditions ( $\mathrm{pH}$ from 5.3 to 5.5) compared to many other low-temperature vents, inducing an important "chemical weathering" process of the volcanic rocks by carbonic acid. Although on occasion, aqueous sulfur species have been observed in Loihi's warmest vent fluids $\left(\sim 50^{\circ} \mathrm{C}\right)$ using in-situ measurements (Glazer and Rouxel, 2009), Loihi vents lack $\mathrm{H}_{2} \mathrm{~S}$ enrichment, which contrasts with typical seafloor hydrothermal systems at mid-oceanic ridges (MOR). Another important feature of hydrothermal fluids at Loihi is that $\mathrm{Mg}$ concentrations remain 
very close to background seawater, precluding the determination of "zero Mg" hydrothermal fluid end-members as is classically done for high-temperature mid-oceanic ridge vents (e.g. Von Damm et al., 1985).

It has been well recognized that Loihi vent fields support abundant and diverse prokaryotic populations, particularly among the Fe-oxidizing bacteria $(\mathrm{FeOB})$. Likewise, biological oxidation in the Pele's Pit area at Loihi Seamount has been considered as responsible for $\sim 60 \%$ of the total Fe-oxidation (Emerson and Moyer, 2002) and the formation of extensive seafloor Fe oxide deposits, referred to as microbial mats and modern analogues of umber deposits (Edwards et al., 2011). A variety of filamentous, non-filamentous, tubular, and branching particles have been recognized in the microbial mats (Karl et al., 1988; Emerson and Moyer, 2002; Fleming et al. 2013) with a mineralogy that includes ferrihydritelike phases with short-range structural order (Toner et al., 2012). In such Fe-rich hydrothermal deposits, silica concentrations are also enriched, and $\mathrm{Si}$ occurs as either amorphous opal and/or Fe-rich smectite (De Carlo et al., 1983).

Our study involves a diverse set of samples, including hydrothermal fluids and Fe-rich deposits recovered during three cruises between 2006 and 2007 as part of the FeMO microbial observatory project (Glazer and Rouxel, 2009; Edwards et al., 2011). The samples are from three actively venting areas located at the summit of Loihi (Fig. 1): (1) Pele's Pit crater which includes Spillway Area (Markers M34 and M38) and Hiolo Area (Markers M36 and M39); (2) Lohiau Area (Markers M2 and M5) located northern of Pele's Pit crater; (3) Pohaku Area (Marker M57) located southern of Pele's Pit. In general, vent fluids ranged in temperature from $21^{\circ} \mathrm{C}$ to $55^{\circ} \mathrm{C}$ with a $\mathrm{pH}$ between 5.6 and 7.3.

In order to compare with the low temperature hydrothermal systems at Loihi, we also reported Ge isotope signatures of high temperature hydrothermal systems from the East Pacific Rise (EPR) at $9^{\circ} 50^{\prime} \mathrm{N}$. This system is located on a fast-spreading ridge and is characterized by higher temperature (up to $350^{\circ} \mathrm{C}$ ) and lower $\mathrm{pH}$ (between 3.1 and 4.1) than Loihi Seamount. This high temperature venting site has been extensively investigated in previous studies (Haymon et al., 1993; Fornari et al., 1998; Shank et al., 1998; Von Damm, 2000; Von Damm, 2004; John et al., 2008; Rouxel et al., 2008). Hydrothermal fluid samples from EPR 9-10 were recovered during cruise AT11-20, covering a range of vent temperatures from $200^{\circ} \mathrm{C}$ to $380{ }^{\circ} \mathrm{C}$ which are associated with chalcopyrite, pyrite and sphalerite-rich chimneys. The hydrothermal field at EPR 9-10 N represents one of the youngest and most studied hydrothermal fields (e.g. Von Damm, 2004), thus permiting the 
investigation of $\mathrm{Ge}$ isotope systematics in an environment where subsurface sulfide remobilization is likely limited, allowing the determination of representative Ge isotope composition for high temperature hydrothermal vents. Vent fluid chemistry and chimney mineralogy have been already reported elsewhere, including Fe, S and Zn isotopes (John et al., 2008; Rouxel et al., 2008).

\section{Methods}

During expeditions with ROV Jason-II (operated by the Woods Hole Oceanographic Institution), vent fields at Loihi seamount were widely surveyed in real-time using in situ voltammetry and temperature sensors (Glazer and Rouxel, 2009), and fluids were sampled using $750 \mathrm{~mL}$ titanium samplers ("Major" Ti- samplers) inserted directly into the vent orifice and triggered by a spring-loaded piston mechanism (Von Damm et al., 1985). Upon recovery on the ship, the samples were immediately filtered $(0.2 \mu \mathrm{m}$ filter pore size $)$ and acidified to $0.06 \mathrm{M} \mathrm{HCl}$. Detailed sample preparation and geochemical analysis procedures are reported in Glazer and Rouxel (2009). Briefly, fluid compositions (Table 1) were determined by ICP-MS (Thermo-Fisher Element 2) after 1:7 dilution with $0.28 \mathrm{M} \mathrm{HNO}_{3}$ and appropriate standardization using matrix-matched standards. Seafloor Fe-rich particulate deposits were collected using the ROV Jason-II suction sampler (Edwards et al., 2011). The sampler is equipped with $5 \mathrm{~L}$ canisters that were flushed between each sampling operation to limit contamination between samples. Once retrieved, the canisters were sub-sampled for various chemical, mineralogical, and biological analyses. Particulates were separated from seawater by centrifugation, air-dried at $30^{\circ} \mathrm{C}$, and powdered in agate mortar. Major and trace elements were analyzed at Activation Laboratories (Ancaster, Ontario) by ICP-AES and ICP-MS, respectively, after lithium metaborate/tetraborate fusion. Only selected major element concentrations ( $\mathrm{Si}, \mathrm{Al}, \mathrm{Fe}$ and $\mathrm{P}$ ) are reported in Table 2 with an overall precision of 5\% (2RSD) and detection limits below $0.01 \mathrm{wt} \%$. Ge concentrations were obtained by isotope dilution and after chemical purification in the same split used for Ge isotope ratios measurements, as described below. Precision and detection limit for Ge concentrations analysis are better than $2 \%(2 \mathrm{RSD})$ and $0.01 \mathrm{\mu g} / \mathrm{g}$ respectively.

Ge isotope ratios and Ge concentrations were determined on MC-ICP-MS (Neptune, Thermo Scientific) at WHOI and IFREMER using the hydride generation technique described in Rouxel et al. (2006) and further modified in Escoube et al. (2012) using a ${ }^{73} \mathrm{Ge}:{ }^{70} \mathrm{Ge}$ double spike addition method. The analytical procedure is summarized below. The Fe-rich 
hydrothermal deposits were first dissolved using concentrated distilled $\mathrm{HNO}_{3}$. After complete evaporation at $\sim 80^{\circ} \mathrm{C}$ on a hot plate, the samples were further dissolved in $40 \mathrm{~mL}$ of $1 \mathrm{M} \mathrm{HF}$ solution (ultra-pure reagent grade) followed by an appropriate addition of Ge double spike (spike/natural ratio between 1 and 2). For sulfide minerals, samples were dissolved with concentrated distilled $\mathrm{HNO}_{3}$ but not spiked, as described in Rouxel et al. (2006). For hydrothermal fluids, between 5 to $25 \mathrm{~mL}$ of sample solution was directly diluted to $40 \mathrm{~mL}$ with a $1 \mathrm{M} \mathrm{HF}$ concentration prior to adding Ge double spike and undertaking column separation. The sample solution in $1 \mathrm{M}$ HF was then purified on an anion exchange chromatographic column (AG1-X8) as described in Rouxel et al. (2006). The total amounts of Ge processed through the entire chemical purification ranged from $40 \mathrm{ng}$ for hydrothermal fluids to $200 \mathrm{ng}$ for mineral deposits, yielding final Ge solution concentrations (in $0.28 \mathrm{M}$ $\mathrm{HNO}_{3}$ ) from $20 \mathrm{\mu g} / \mathrm{g}$ to $100 \mathrm{\mu g} / \mathrm{g}$ for isotopic analysis. The contribution of Ge from the whole procedural chemistry blank was measured for each batch of samples and has been found to be in all cases below $10 \mathrm{pg}$ and indistinguishable from the instrumental blank determined by measuring pure $0.28 \mathrm{M} \mathrm{HNO}_{3}$ solutions.

The MC-ICP-MS at WHOI and IFREMER was operated at low-mass resolution mode and ${ }^{70} \mathrm{Ge},{ }^{72} \mathrm{Ge},{ }^{73} \mathrm{Ge}$ and ${ }^{74} \mathrm{Ge}$ were measured on L2, C, H1, and $\mathrm{H} 2$ cups while ${ }^{68} \mathrm{Zn},{ }^{69} \mathrm{Ga}$, ${ }^{71} \mathrm{Ga}$ and ${ }^{77} \mathrm{Se}$ were also monitored on L4, L3, L1 and H4 cups. The continuous flow hydride generation introduction system consisted of the CETAC HGX-200 directly connected to the ICP torch. Instrumental mass bias was corrected using two alternative techniques depending on sample types: (1) a double spike correction was performed for hydrothermal fluids and mineral samples from Loihi following a data reduction scheme similar to Siebert et al. (2006); (2) a sample-standard bracketing technique was applied to the analysis of sulfide minerals from EPR, following the approach of Rouxel et al. (2006).

The double spike was prepared from Ge metal spikes ${ }^{73} \mathrm{Ge}$ and ${ }^{70} \mathrm{Ge}$ purchased from Isoflex USA (Ge-70 \#32-01-70-3259 and Ge-73 \#32-01-73-1405). Each spike was dissolved separately and we obtained the following composition for the double spike: ${ }^{74} \mathrm{Ge} /{ }^{70} \mathrm{Ge}=$ $0.07614 \pm 0.00010 ;{ }^{73} \mathrm{Ge} /{ }^{70} \mathrm{Ge}=0.60707 \pm 0.00008 ;{ }^{72} \mathrm{Ge} /{ }^{70} \mathrm{Ge}=0.05626 \pm 0.00008(2 \mathrm{sd}$ uncertainties).

Ge isotope ratios were reported as $8^{4 / 70} \mathrm{Ge}$ values according to the following equation:

$$
\delta^{74 / 70} G e=\left(\frac{\left({ }^{74} G e l^{70} G e\right)_{\text {sample }}}{\left({ }^{74} G e l^{70} G e\right)_{\text {NIST3120a }}}-1\right) \times 1000
$$


Chemical compositions for hydrothermal fluids and deposits are reported in Tables 1 to 3. Te NIST3120a (Lot \#000411, $1000 \mu \mathrm{g} / \mathrm{g}$ ) standard has been calibrated against previously used standards as reported in Escoube et al. (2012). Relative to NIST 3120a, the bulk crust, including both oceanic and continental crusts, has an average $8^{4 / 70} \mathrm{Ge}$ value of 0.59 $\pm 0.18 \%$ o (2sd). The external 2 sd uncertainties of the $8^{4 / 70} \mathrm{Ge}$ values were obtained through duplicated chemical purification and isotopic analysis of NIST 3120a standards and BHVO-2 obtained during the same analytical sessions.

A number of Geochemical Reference Materials (GRM) and standard solutions were already reported in Escoube et al. (2012). Average values for igneous rocks GRM (BHVO-2; BIR-1; BCR-1) yielded very limited variations, with $8^{4 / 70} \mathrm{Ge}=0.56 \pm 0.08 \%$. We also measured iron formation IF-G (IWG-GIT) and marine sediment GL-O (ANRT) and obtained $\delta^{4 / 70} \mathrm{Ge}$ values of $1.03 \pm 0.10 \%$ (2sd) and $2.44 \pm 0.14 \%$ (2sd) respectively.

\section{Results}

\subsection{Hydrothermal fluids}

Loihi vent fluids had a maximum temperature of $55^{\circ} \mathrm{C}$ and were all enriched in $\mathrm{Fe}$, $\mathrm{Mn}, \mathrm{Si}$ and Ge relative to background seawater (Table 1). As already discussed in previous studies (Karl et al., 1988; Sedwick et al., 1992; Wheat et al., 2000; Glazer and Rouxel, 2009), the positive correlation between $\mathrm{Si}, \mathrm{Fe}$ and $\mathrm{Mn}$ concentrations reflects simple dilution with background seawater, either during fluid sampling or in the subsurface (Fig. 2).

Due to their relatively homogeneous Fe/Mn ratios ranging from 22 to $41 \mu \mathrm{mol} / \mathrm{mol}$ (average of $27 \mu \mathrm{mol} / \mathrm{mol}$ ), Pele's Pit vents (Markers M34, M36, M38 and M39) were considered to be derived from the same fluid source at depth (hereafter referred to as fluid end-member) (Glazer and Rouxel, 2009). The lowest Fe/Mn ratios, associated with lower temperature vent fluids (below $25^{\circ} \mathrm{C}$ ), were reported at the Northern part of Pele's Pit (i.e. Lohiau) and reflected subsurface Fe oxidation and precipitation (Glazer and Rouxel, 2009). Pohaku vents (M57), located south of Pele's Pit were also characterized by lower temperatures $\left(28^{\circ} \mathrm{C}\right.$ maximum) but with higher $\mathrm{Fe} / \mathrm{Mn}$ ratios suggestive of subsurface interactions with volcanic rocks (Glazer and Rouxel, 2009).

Ge concentration in hydrothermal fluids at Loihi ranged from 10 to $180 \mathrm{nM}$, which is up to 3 orders of magnitude higher than seawater (e.g. Froelich et al., 1989; Mortlock and 
Froelich, 1996). Si concentrations in Loihi vent fluids have been previously used as tracers of hydrothermal vent fluid dilution with seawater (Sedwick et al., 1992; Wheat et al., 2000; Glazer and Rouxel, 2009). Hence, the linear correlation between Ge and Si at Pele's Pit (markers M36, 39, 34, 38, 2, 5) with $\mathrm{Ge} / \mathrm{Si}$, at around $29.6 \pm 1.6 \mu \mathrm{mol} / \mathrm{mol}$, suggests that the overall variability of Ge concentration in vent fluids was mainly the result of fluid dilution with seawater (Fig. 2a). Pohaku vent fluids had distinctly lower $\mathrm{Ge} / \mathrm{Si}$ ratios at around 8 $\mu \mathrm{mol} / \mathrm{mol}$ confirming assumptions based on $\mathrm{Fe} / \mathrm{Mn}$ ratios that different hydrothermal fluid end-members were venting at this site (Glazer and Rouxel, 2009).

High temperature hydrothermal fluids from EPR 9-10 $\mathrm{N}$ were also enriched in Ge vs. Si compared to source rocks (i.e. basalt with $\mathrm{Ge} / \mathrm{Si}=2.4 \mu \mathrm{mol} / \mathrm{mol}$ ) with $\mathrm{Ge} / \mathrm{Si}$ ratios between 3.7 and $8.5 \mu \mathrm{mol} . \mathrm{mol}^{-1}$. Those values were lower than Pele's Pit vent fluids but consistent with other high temperature vent fluids from EPR $21^{\circ} \mathrm{N}$ and Juan de Fuca Ridge (Mortlock et al., 1993) (i.e. Ge/Si between 5 and $15 \mu \mathrm{mol} / \mathrm{mol}$ ) (Table 4). In comparison, studies of Ge/Si in warm hydrothermal fluids from the ridge flank reported Ge/Si up to $60 \mu \mathrm{mol} / \mathrm{mol}$, while cold formation fluids on ridge flanks yielded Ge/Si closer to basalt values (Wheat and McManus, 2008) (Table 4).

Pele's Pit vent fluids (markers M34, M36, M38 and M39) had $8^{4 / 70} \mathrm{Ge}$ values ranging from 1.2 to $2.2 \%$ o, averaging $1.68 \pm 0.70 \%$ o $(2 \mathrm{sd})$ and were thus systematically heavier than basaltic values defined at $0.56 \%$ (Rouxel et al., 2006; Siebert et al., 2011; Escoube et al., 2012) (Table 1, Fig. 3). Those $\delta^{4 / 70} \mathrm{Ge}$ values were, however, lighter than seawater $\left(8^{4 / 70} \mathrm{Ge}\right.$ estimated at $3 \%$ ), which has been estimated at around $2.5 \%$ using deep-sea sponge values (Rouxel et al., 2006). Vent fluids from Lohiau and Pohaku areas had $\delta^{4 / 70} \mathrm{Ge}$ values between 0.95 to $1.23 \%$ and 0.61 to $0.74 \%$ respectively, and were thus lower than values obtained in Pele's Pit.

High temperature vent fluids from EPR $9-10^{\circ} \mathrm{N}$ yield $8^{4 / 70} \mathrm{Ge}$ values averaging $1.55 \pm$ $0.36 \%$ o $(2 \mathrm{sd}, \mathrm{n}=6)$ and were similar, albeit slightly lower, than the average $\delta^{4 / 70} \mathrm{Ge}$ value of low temperature hydrothermal fluids at Pele's Pit (Tables 1 and 4). Hence, despite their fundamental differences in temperature and chemical composition, high and low temperature hydrothermal vent fluids showed similar Ge isotope compositions characterized by a global enrichment in heavy Ge isotopes of about $1 \%$ relative to the basaltic source.

\subsection{Seafloor hydrothermal deposits}


At Loihi Seamount, hydrothermal deposits were composed essentially of $\mathrm{Fe}$ oxyhydroxides and amorphous silica, which was reflected by the total $\mathrm{Fe}$ and $\mathrm{Si}$ concentrations up to $40 \mathrm{wt} \%$ and $15 \mathrm{wt} \%$, respectively (Table 2). Significant amounts of goethite, Fe-montmorillonite and nontronite were reported in previous studies (De Carlo et al., 1983 ) but XRD analysis of our samples suggested only minor amounts of these clay minerals. Aluminium concentrations, reaching up to $2.3 \mathrm{wt} \%$ in some samples, were related to the addition of small amounts of volcanic glass fragments that had been entrained during mat sampling at the seafloor.

Ge concentrations in Loihi deposits range from 4.8 to $29.5 \mu \mathrm{g} / \mathrm{g}$, with $\mathrm{Ge} / \mathrm{Si}$ ratios from 37.5 to up to $189 \mu \mathrm{mol} / \mathrm{mol}$ (Table 3), which is one order of magnitude higher than for the associated hydrothermal fluids ( $\mathrm{Ge} / \mathrm{Si}$ at around $31 \mu \mathrm{mol} / \mathrm{mol}$ ). Bulk $\mathrm{Ge}$ isotope compositions of Loihi Fe-rich deposits yield $8^{4 / 70} \mathrm{Ge}$ values between 0.16 and $-0.98 \%$, lighted than basalt $\left(8^{4 / 70} \mathrm{Ge}=0.56 \%\right.$ ) and hydrothermal fluid values.

At EPR $9^{\circ} 50^{\prime} \mathrm{N}$, hydrothermal deposits, including active and inactive chimneys, were composed of sulfide minerals such as chalcopyrite, pyrite, marcasite and sphalerite (Rouxel et al., 2008). Only Ge-enriched sulfides (i.e. sphalerite, pyrite, and marcasite) were analyzed for Ge isotope ratios (Table 3). Results showed systematically light $\delta^{4 / 70} \mathrm{Ge}$ values (down to $4.71 \%$ ), which are in marked contrast with the systematic heavy $\delta^{4 / 70} \mathrm{Ge}$ values of the hydrothermal fluid recovered from the same chimney at around $1.55 \%$.

\section{Discussion}

\subsection{Coupled Ge/Si and Ge-isotope systematics in hydrothermal fluids}

It has been already demonstrated that $\mathrm{Ge} / \mathrm{Si}$ ratios in geothermal waters and hydrothermal fluids are systematically higher than $\mathrm{Ge} / \mathrm{Si}$ ratios in source rocks (Arnorsson, 1984; Criaud and Fouillac, 1986; Evans and Derry, 2002). This enrichment may result from the preferential partitioning of $\mathrm{Ge}$ vs. $\mathrm{Si}$ in the fluid, considering the contrasting thermodynamic properties of aqueous $\mathrm{Ge}(\mathrm{OH})_{4}$ and $\mathrm{Si}(\mathrm{OH})_{4}$ in equilibrium with Ge-bearing silicates (Arnorsson, 1984; Pokrovski and Schott, 1998; Pokrovski et al., 2005). Experimental results show that Ge/Si ratio in hydrothermal fluid in equilibrium with quartz decreases with increasing temperature from $160 \mu \mathrm{mol} / \mathrm{mol}$ at $50^{\circ} \mathrm{C}, 43 \mu \mathrm{mol} / \mathrm{mol}$ at $250^{\circ} \mathrm{C}$ to about 30 $\mu \mathrm{mol} / \mathrm{mol}$ at $400^{\circ} \mathrm{C}$ (Pokrovski and Schott, 1998; Evans and Derry, 2002). 
Based on field data, Evans and Derry (2002) also proposed a model of progressive Si loss via precipitation of Ge-poor quartz (i.e. Rayleigh distillation) in order to explain the extreme increase of the Ge/Si ratio in cooled hydrothermal fluids. This model, requiring a high level of Si loss along a reaction path in order to produce observed $\mathrm{Ge} / \mathrm{Si}$ ratios, is however not applicable to seafloor hydrothermal systems. The main reason is that measured Si concentrations of hydrothermal fluids, both at Loihi and EPR $9^{\circ} 50^{\prime} \mathrm{N}$, are in equilibrium with quartz at the temperature and pressure (i.e. depth) corresponding of the base of the upflow zone at high temperature $\left(>300^{\circ} \mathrm{C}\right.$ ) (Mottl, 1983; Von Damm et al., 1991; Sedwick et al., 1992). As suggested by Sedwick et al. (1992), the Si vs. T relationship at Loihi suggests saturation with quartz at high temperature $\left(>300^{\circ} \mathrm{C}\right)$, which suggests that the high $\mathrm{Si}$ concentrations (up to $4 \mathrm{mM}$ ) at Loihi result from the contribution of high-temperature fluid in the subsurface. Using a Si-T diagram, the same authors also suggest that the decrease of $\mathrm{Si}$ concentration in the fluid is only due to dilution during mixing with seawater and that no precipitation of Si occurs during the upflow and cooling of the hydrothermal fluids. At EPR $9^{\circ} 50^{\prime} \mathrm{N}$, both $\mathrm{Ge} / \mathrm{Si}(\sim 8 \mu \mathrm{mol} / \mathrm{mol})$ and Si concentrations $(\sim 20 \mathrm{mM})$ are also consistent with thermodynamic data, suggesting that equilibrium with quartz occurs in the reaction zone at temperatures between $350^{\circ} \mathrm{C}-400^{\circ} \mathrm{C}$. Hence, it is unlikely that a significant amount of $\mathrm{Si}$ precipitated during fluid upflow. This is consistent with the general model that hydrothermal solutions rise adiabatically through the upflow zone and neither gain nor lose $\mathrm{Si}$ as they rise, in spite of the high degree of quartz supersaturation that results from the drop in pressure (Von Damm et al., 1991).

Here, we further evaluate whether both high $\mathrm{Ge} / \mathrm{Si}$ ratios and heavy $8^{4 / 70} \mathrm{Ge}$ values of hydrothermal fluids compared to source rocks may be explained by mineral-fluid partitioning in the reaction zone (i.e. batch fractionation). Because Si concentration in high-temperature hydrothermal fluids is controlled by quartz solubility (VonDamm et al., 1991), higher Ge/Si ratios in hydrothermal fluids venting at the seafloor may be buffered by quartz in the reaction zone (Mortlock et al., 1993; Wheat and McManus, 2005). Considering that processes affecting $\mathrm{Ge} / \mathrm{Si}$ ratios may also fractionate Ge isotope ratios, we propose a model linking $\mathrm{Ge} / \mathrm{Si}$ ratios and Ge isotope compositions in hydrothermal fluid in equilibrium with quartz (or other silicates) in the reaction zone. In this case, we can estimate the Ge-isotope fractionation factors between quartz (or other silicates) and fluid using the following mass balance equation: 


$$
\delta^{74 / 70} G e_{\text {Basalt }}=\mathrm{X}_{\text {Fluid }} \times \delta^{74 / 70} G e_{\text {Fluid }}+\left(1-\mathrm{X}_{\text {Fluid }}\right) \times \delta^{74 / 70} G e_{Q z}
$$

(Eq.

2)

Where $8^{4 / 70} \mathrm{Ge}_{\text {Basalt }}, 8^{4 / 70} \mathrm{Ge}_{\text {Fluid, and }} 8^{4 / 70} \mathrm{Ge}_{\mathrm{Qz}}$, the Ge isotopic composition of basalt, fluid and quartz respectively. $\mathrm{X}_{\text {Fluid, }}$, the fraction of Ge partitioned in the fluid can be estimated using Ge/Si relationships, such as:

$$
X_{\text {Fluid }}=\frac{\mathrm{G} e / S i_{\text {Basalt }}-K_{d} \times \mathrm{Ge} / S i_{\text {Fluid }}}{\mathrm{G} e / S i_{\text {Basalt }} \times\left(1-K_{d}\right)}
$$

where $\mathrm{K}_{\mathrm{d}}$, the partition coefficient defined as the ratio of $\mathrm{Ge} / \mathrm{Si}$ in quartz relative to the solution: $\mathrm{K}_{\mathrm{d}}=(\mathrm{Ge} / \mathrm{Si})_{\mathrm{Qz}} /(\mathrm{Ge} / \mathrm{Si})_{\text {Fluid }}$

Using $8^{4 / 70} \mathrm{Ge}_{\text {Basalt }}=0.56 \%$, Ge/Si $i_{\text {Basalt }}=2.20 \mu \mathrm{mol} / \mathrm{mol}$ (Escoube et al., 2012), $\mathrm{K}_{\mathrm{d}}=$ 0.02 (Evans and Derry, 2002); and $8^{4 / 70} \mathrm{Ge}_{\text {Fluid }}$ and $\mathrm{Ge} / \mathrm{Si}_{\text {Fluid }}$ measured at Loihi, we obtained $8^{4 / 70} \mathrm{Ge}_{\text {Quartz }}$ values of about $-2.4 \%$ (i.e. $\Delta^{4 / 70} \mathrm{Ge}_{\mathrm{Qz}-\text {-fluid }}$ at about $-4.1 \%$ ). Similar $8^{4 / 70} \mathrm{Ge}_{\text {Quartz }}$ values could be obtained at EPR using $\mathrm{K}_{\mathrm{d}}=0.12$. Although those values are highly sensitive to the choice of $K_{d}$ values (Eq. 3), the results suggest that quartz precipitation favours the light Ge isotopes, as already suggested by Rouxel et al. (2006) and Siebert et al. (2011). It is important to note that theoretical calculations by $\mathrm{Li}$ et al. (2009) predict an opposite fractionation factor for quartz, with $\Delta^{4 / 70} \mathrm{Ge}_{\text {Qz-Fluid }}$ of $\sim 0 \%, 0.63 \%$ and $1.0 \%$ at $450^{\circ} \mathrm{C}$, $100^{\circ} \mathrm{C}$ and $40^{\circ} \mathrm{C}$ respectively which is at odds with field studies. Hence, further work is required to experimentally determine the $\mathrm{Ge}$ isotope fractionation factor between silicate minerals and fluid at hydrothermal temperature $\left(>350^{\circ} \mathrm{C}\right)$. This issue can be also addressed by the analyses of quartz veins in both high- and low-temperature altered basalts.

An additional possibility explaining heavier $\delta^{4 / 70} \mathrm{Ge}$ values in vent fluids relative to source rocks may be related to differences of reactivity of Ge and Si towards sulfides in the reaction zone. In a growing number of studies (Li et al., 2009; Escoube et al., 2012; Belissont et al., 2014), it has been shown that Ge isotopes are significantly fractionated during $\mathrm{Ge}$ incorporation in sulfides. In particular, results reported in Table 3 show that Ge isotope composition in hydrothermal sulfides at Bio 9" vent may be up to $-6.05 \%$ \% $(-5.6 \pm 0.6 \%$ o, $2 \mathrm{sd}$ on average) lower than in associated fluids even at hydrothermal temperature (see section 5.4 
and Table 1). It has been tentatively proposed by Escoube et al. (2012) that such large Ge isotope fractionation between sulfides and fluids may be related to the preferential substitution of $\mathrm{Ge}^{\mathrm{II}}$ in sulfides. Hence, the increase of $\mathrm{Ge} / \mathrm{Si}$ ratios and heavier $\delta^{4 / 70} \mathrm{Ge}$ values of seafloor hydrothermal fluids cannot be explained solely by sulfide precipitation. In addition, considering that both high- and low-temperature vent fluids have higher Ge/Si ratios and $8^{4 / 70} \mathrm{Ge}$ values, we do not favour the hypothesis that Ge sequestration in quartz during fluid upflow (i.e. Rayleigh distillation mechanism) is an effective mechanisms to affect Ge/Si and $8^{4 / 70} \mathrm{Ge}$ values. Therefore, we suggest that both quartz and sulfide precipitation in the reaction zone should act in conjunction to control both $\mathrm{Ge} / \mathrm{Si}$ and $\mathrm{Ge}$ isotope signatures in seafloor hydrothermal fluid.

\subsection{Importance of subsurface processes in affecting Ge geochemistry in hydrothermal fluids}

Although all vents in the Pele's Pit hydrothermal field are likely fed by the same endmember fluid at depth, there was significant variability in $\mathrm{Ge} / \mathrm{Si}, \mathrm{Fe} / \mathrm{Mn}$ and $8^{4 / 70} \mathrm{Ge}$ between vent sites or sampling periods. Since both Fe/Mn and Ge/Si ratios at Loihi are not affected by vent fluid mixing with seawater, it may be expected that vent fluids affected by subsurface mineral precipitation/dissolution processes could be distinguished using their Fe/Mn vs. Ge/Si relationships.

Hydrothermal fluids from marker M5 yield the most variable $\mathrm{Ge} / \mathrm{Si}$ and $\mathrm{Fe} / \mathrm{Mn}$. In particular, Ge/Si range from 21 to $52 \mu \mathrm{mol} / \mathrm{mol}$, being both the lowest and highest values found in Pele's Pit (Table 1). Although no clear systematics between Fe/Mn and Ge/Si ratios can be observed (Fig. 2), the close proximity of M5 relative to other Pele's Pit vents suggests similar end-member fluid values. Hence, the variable $\mathrm{Ge} / \mathrm{Si}$ ratios and lower Fe/Mn ratios may be due to subsurface reactions during cooling of the fluids beneath the Fe-rich deposits. M5 also features the lowest $8^{4 / 70} \mathrm{Ge}$ values at Pele's Pit at $1.13 \pm 0.25 \%$ on average (Fig. 3, Table 1). Since the M5 area lacks a well-defined outflow zone and is intensively covered by thick Fe-rich deposits (Glazer and Rouxel, 2009), it is possible that lower $\delta^{4 / 70} \mathrm{Ge}$ values associated with higher $\mathrm{Ge} / \mathrm{Si}$ were due to $\mathrm{Ge}$ leaching from the surrounding seafloor hydrothermal deposits having lighter $8^{4 / 70} \mathrm{Ge}$ values and higher Fe/Mn and $\mathrm{Ge} / \mathrm{Si}$ ratios.

Hydrothermal fluids from marker M57 yielded lower Ge/Si ratios, averaging 7.9 \pm 1.3 $\mu \mathrm{mol} / \mathrm{mol}$, and higher Fe/Mn ratios, which likely reflect a different pathway of hydrothermal 
fluids relative to Pele's Pit vents (Table 1). M57 was also characterized by lighter $8^{4 / 70} \mathrm{Ge}$ values compared to Pele's Pit fluids, bringing the isotope composition closer to basalt values (Fig. 3). Lower Fe/Mn ratios at M57 have already been interpreted as reflecting a stronger interaction with basalt during fluid circulation (Glazer and Rouxel, 2009) due to longer residence time of the fluid in subsurface environments (Wheat et al., 2000). More intense weathering (i.e. near congruent dissolution due to $\mathrm{CO}_{2}$-induced alteration) provides an adequate explanation for lower $\mathrm{Ge} / \mathrm{Si}$ and $8^{4 / 70} \mathrm{Ge}$ values that are intermediate between Pele's Pit vents and basalts.

\subsection{The geochemistry of Ge isotopes in Fe-rich hydrothermal deposits at Loihi}

The Fe-rich hydrothermal deposits at Loihi are related to the formation of extensive Fe-rich microbial mats formed by the oxidation of hydrothermally-derived $\mathrm{Fe}$ at or below the seafloor (De Carlo et al., 1983; Karl et al., 1988). Iron precipitation is considered to result mainly from microbial oxidation mediated by neutrophilic Zetaproteobacteria, which have been estimated to contribute to $\sim 60 \%$ of total $\mathrm{Fe}$ oxidation of the hydrothermal fluids circulating through the microbial mats (Emerson and Moyer, 2002; Emerson et al., 2007). Reactive oxyanions in vent fluids and seawater, such as phosphate and germanic acid $\left(\mathrm{H}_{4} \mathrm{GeO}_{4}\right)$ are readily adsorbed onto goethite and ferrihydrite and coprecipitate with amorphous Fe oxyhydroxides particulates. P and Ge are therefore significantly enriched in the Fe-rich deposits at Loihi Seamount (Table 2). Upon oxidative precipitation of Fe, amorphous silica from the hydrothermal fluid may also precipitate. It is important to note that Fe sulfide minerals are absent at Loihi (Toner et al., 2012), mainly because of the lack of $\mathrm{H}_{2} \mathrm{~S}$ in the hydrothermal fluids (Glazer and Rouxel, 2009). It should be also noted that the low organic C content of the mats, as well as the development of microaeorophilic conditions, preclude active microbial sulfate and iron reduction, which is generally observed in reducing marine sediments. The preferential enrichment of Ge vs. Si in Fe-rich mineral deposits has been reported in numerous studies and interpreted as resulting from the strong affinity of $\mathrm{Ge}$ toward Fe oxyhydroxides (Bernstein, 1985; Kurtz et al., 2002; Pokrovsky et al., 2006; Pokrovsky et al., 2014). Hence, Ge in the Fe-rich hydrothermal deposits is potentially hosted in three pools (1) Fe oxyhydroxides, (2) amorphous silica, and (3) volcanic debris.

The Fe-rich deposits at Loihi Seamount have low $8^{4 / 70} \mathrm{Ge}$ values from 0.16 down to -

$0.98 \%$ (Table 2), which corresponds to a maximum apparent $\Delta^{4 / 70} \mathrm{Ge}_{\text {deposit-fluid }}$ of $-2.81 \%$ o 
(Fig. 3). The largest fractionation factor between fluid and Fe-rich deposit is broadly consistent with experimental data for Ge coprecipitation with amorphous iron oxyhydroxide up to $-4.4 \%$ (Pokrovsky et al., 2014). However, since $8^{4 / 70} \mathrm{Ge}$ signatures in microbial mats are muted by the relative proportion of Ge hosted in amorphous silica, basalt fragments or Fe oxyhydroxides, the $8^{4 / 70} \mathrm{Ge}$ values of the pure Fe oxyhydroxide end-member should be calculated using the following mass balance equation:

$$
\delta^{74} G e_{\text {deposit }}=\mathrm{XGe}_{\mathrm{Bas}} \times \delta^{74} G e_{\mathrm{Bas}}+\mathrm{XGe}_{\mathrm{Amo}} \times \delta^{74} G e_{\mathrm{Amo}}+X G e_{\mathrm{FeOOH}} \times \delta^{74} G e_{\mathrm{FeOOH}}(\mathbf{E q} \cdot \mathbf{4})
$$

with $\mathrm{XGe}$, the fraction of mass $\mathrm{Ge}$ in each component (Bas: basalt; Amo: amorphous silica; FeOOH: Fe oxyhydroxide).

The fraction of $\mathrm{Ge}$ in basalt $\left(\mathrm{XGe}_{\mathrm{Bas}}\right)$ can be calculated using $\mathrm{Al}$ concentration, if we consider that $\mathrm{Al}$ is only hosted in the basalt component:

$$
X G e_{\text {Bas }}=\left(\frac{A l}{G e}\right)_{\text {measured }} \times\left(\frac{S i}{A l}\right)_{\text {Bas }} \times\left(\frac{G e}{S i}\right)_{\text {Bas }}
$$

With $\mathrm{Al} / \mathrm{Ge}_{\text {measured }}$ the measured ratio in the mat (in $\mathrm{g} / \mathrm{g}$ ); $\mathrm{Si} / \mathrm{Al}_{\mathrm{Bas}}$ the average ratio previously reported for basalts at Loihi (Frey and Clague, 1983) equal to 2.95; and $\mathrm{Ge} / \mathrm{Si}_{\mathrm{Bas}}$ the average ratio reported for basaltic rocks around $5.7 \mu \mathrm{g} . \mathrm{g}^{-1}$ (i.e. $2.2 \mu$ mol.mol-1, De Argollo and Schilling, 1978; Halicz, 1985; Kurtz et al., 2002). The Ge isotope composition of the basalt pool is also taken from the average crustal (i.e., oceanic and continental crusts) values defined at $8^{4 / 70} \mathrm{Ge}_{\mathrm{Bas}}=0.56 \%$ (Rouxel et al., 2006; Escoube et al., 2012).

The fraction of $\mathrm{Ge}$ in amorphous silica $\left(\mathrm{XGe}_{\mathrm{Amo}}\right)$ can be also estimated, according to the equation:

$$
X G e_{\text {Amo }}=\frac{K_{d}}{G e_{\text {measured }}} *\left(\frac{G e}{S i}\right)_{\text {fluid }} \times\left[S i_{\text {measured }}-A l_{\text {measured }}\left(\frac{S i}{A l}\right)_{\text {Bas }}\right] \text { (Eq. 6) }
$$

Where $\mathrm{K}_{\mathrm{d}}=(\mathrm{Ge} / \mathrm{Si})_{\mathrm{Amo}} /(\mathrm{Ge} / \mathrm{Si})_{\text {Fluid. }} . \mathrm{K}_{\mathrm{d}}$ is potentially equal to unity (i.e. no fractionation) as is the case for biogenic opal precipitation (Lewin, 1966; Azam et al., 1974; Azam and Volcani, 1981; Froelich and Andreae, 1981; Murnane and Stallard, 1988; Froelich et al., 1992; Bareille et al., 1998) or lower than unity at about 0.02 as is the case for quartz 
precipitation (Evans and Derry, 2002). Note that the amount of Si derived from direct fluid precipitation is corrected for basalt contributions in Eq. 6.

The Ge isotope composition of the amorphous silica pool is, at a first approximation, taken to be equal to the composition of the hydrothermal fluid, which is consistent with biogenic opal precipitation which appears to not fractionate Ge isotope significantly (Mantoura, 2006). However, this issue will need to be re-evaluated when experimental studies become available. Finally, the fraction of $\mathrm{Ge}$ in $\mathrm{FeOOH}$ is determined as the residual Ge pool such that:

$$
\mathrm{XGe}_{\mathrm{FeOOH}}=1-\mathrm{XGe}_{\mathrm{Bas}}-\mathrm{XGe}_{\mathrm{Amo}}
$$

Where $\mathrm{XGe}_{\mathrm{Bas}}$ and $\mathrm{XGe}_{\mathrm{Amo}}$ are determined using Eq. 5 and Eq. 6 respectively. This approach allows the Ge isotope composition of the $\mathrm{FeOOH}$ pool to be calculated using equation (Eq. 4) for all samples (Table 4). In order to take into account the measurements uncertainties of input values in equations (Eq. 4-7), we propagated errors using a Monte Carlo simulation at $95 \%$ confidence level. For this stochastic simulation, we propagated uncertainties for both $8^{4 / 70} \mathrm{Ge}$ and $\mathrm{Ge} / \mathrm{Si}$ values of the hydrothermal vent fluids. We also propagated uncertainties in $\mathrm{K}_{\mathrm{d}}$ values, taken at $0.5 \pm 0.4$ which encompasses all $\mathrm{K}_{\mathrm{d}}$ values expected for amorphous silica or silicate precipitation. Results presented in Table $\mathbf{5}$ show that approximately $90 \%$ of total $\mathrm{Ge}$ is associated with iron oxyhydroxides (i.e. $\mathrm{XGe}_{\mathrm{FeOOH}}$ ); except for samples with significant $\mathrm{Si}$ enrichments $\left(\mathrm{XGe}_{a m o}\right.$ up to $\left.27 \%\right)$. For all samples the proportion of detrital (i.e. basaltic) Ge is less than 5\%. It is evident that, for samples having the highest Si enrichment (e.g. J2-308-SS2), the amount of Ge hosted in amorphous silica depends highly on the value of the partition coefficient $\mathrm{K}_{\mathrm{d}}$. For samples with more than $90 \%$ of Ge hosted in Fe-oxyhydroxides, the calculated $\delta^{4 / 70} \mathrm{Ge}_{\mathrm{FeOOH}}$ values are shifted to lighter values by only $0.25 \%$ relative to bulk $8{ }^{4 / 70} \mathrm{Ge}$ values, and therefore very similar within uncertainty.

Using calculated $\delta^{4 / 70} \mathrm{Ge}_{\mathrm{FeOOH}}$ values, it is possible to determine, for each sample, the apparent $\mathrm{Ge}$ isotope fractionation factor between the source fluid and precipitated $\mathrm{Fe}$ oxyhydroxide ( $\Delta^{4 / 70} \mathrm{Ge}$ FeOOH-fluid). The results (Table 5) show a range of $\Delta^{7 / 70} \mathrm{Ge}_{\mathrm{FeOOH} \text {-fluid }}$ values, from $-3.6 \pm 0.9 \%$ (2sd) at M34 to $-0.9 \pm 0.2 \%$ (2sd) at M57. Excluding those 2 extreme values, $\Delta^{4 / 70} \mathrm{Ge}_{\mathrm{FeOOH}-\text { fluid }}$ is rather homogeneous for the Pele's Pit area, with an 
average of $-2.0 \pm 0.6 \%$ ( $2 \mathrm{sd}$ ). In comparison, Pohaku shows smaller $\Delta^{4 / 70} \mathrm{Ge}_{\mathrm{FeOOH} \text { - fluid }}$ at -0.9 $\pm 0.2 \%$ (2sd). By comparison, Pokrovsky et al. (2014) determined the Ge isotope fractionation factor $\alpha k_{\mathrm{eOOH}-\mathrm{Fluid}}$ at about 0.9956 (i.e. $\Delta^{4 / 70} \mathrm{Ge}_{\mathrm{FeOOH}-\mathrm{fluid}}=-4.4 \%$ ) at room temperature demonstrating that light $\mathrm{Ge}$ isotopes are preferentially sequestrated into $\mathrm{Fe}$ oxyhydroxides.

Using first-principles density functional theory, Li and Liu (2010) calculated Ge isotope fractionation factors for the adsorption of aqueous $\mathrm{Ge}$ species onto $\mathrm{Fe}(\mathrm{III})$ oxyhydroxide surfaces. Calculated fractionation factors ranged from -1.5 to $-1.9 \%$ at temperatures between $20^{\circ} \mathrm{C}$ and $50^{\circ} \mathrm{C}$ and were almost insensitive to $\mathrm{pH}$. Hence, our results are consistent with both previous experimental and theoretical studies. Our estimate of $\Delta^{4 / 70} \mathrm{Ge}_{\mathrm{FeOOH}-\mathrm{fluid}}$ at $-2.0 \pm 0.6 \%$ (2sd) is, however, smaller than experimental studies by Pokrovsky et al. (2014), which may be explained by a different coordination configuration of adsorbed Ge as well as competition with others chemical species such as silica. For example, the different (i.e. lower) fractionation factor during Ge sorption at Pohaku may be related to the structure of Fe-oxyhydroxide particles that are distinct from the Pele's Pit area (Haddad et al., in prep).

It is also possible that Ge sorption onto Fe-rich deposits at Loihi does not proceed in a completely open system, i.e. when the rate of Ge precipitation is faster than the supply of $\mathrm{Ge}$ from hydrothermal fluids. In this case, the apparent fractionation factor $\Delta^{4 / 70} \mathrm{Ge}_{\mathrm{FeOOH}-\mathrm{fluid}}$ is related to the amount $\left(\mathrm{f}_{\mathrm{ads}}\right)$ of Ge adsorbed onto Fe oxyhydroxide using the equation:

$$
\Delta^{4 / 70} \mathrm{Ge}_{\mathrm{FeOOH}-\text { fluid }}=\left(1-\mathrm{f}_{\mathrm{ads}}\right) \times 1000 \ln \left(\mathrm{q}_{\mathrm{eOOH}-\text { fluid }}\right)
$$

with $9 \mathrm{k}_{\mathrm{eOH}-\text { fluid }}$ being the equilibrium fractionation factor between $\mathrm{Ge}$ adsorbed onto Fe oxyhydroxide and Ge in solution. Using $\alpha_{01-l i q}$ of about 0.996 as determined by Pokrovsky et al. (2014), we can calculate that $\Delta^{4 / 70} \mathrm{Ge}_{\mathrm{FeOOH} \text {-fluid }}$ of about $-2 \%$ corresponds to more than $30 \%$ of Ge from the hydrothermal fluid that is precipitated within Fe-rich deposits (Table 5). In the case of Pohaku (M57) showing a $\Delta^{4 / 70} \mathrm{Ge}_{\mathrm{FeOOH}-\text { fluid }}$ of $-0.9 \%$, the amount of $\mathrm{Ge}$ precipitation may increase to up to $70 \%$ (Table 5). The fact that more than $30 \%$ of Ge from the hydrothermal fluid may be precipitated at the seafloor suggests that Fe-rich deposits provide a relatively efficient trapping of reactive elements coming from the diffuse vent fluids. This finding contrasts with high-temperature hydrothermal chimneys that behave as an 
open system relative to vent fluids; i.e., only a small fraction of elements is trapped within the chimney wall (Tivey, 1995).

\subsection{Preliminary estimation of Ge fractionation in hydrothermal sulfide deposits}

Through a combined approach using hydrothermal sulfide deposits and associated fluids, we can estimate the apparent $\mathrm{Ge}$ isotope fractionation factor $\left(\Delta^{4 / 70} \mathrm{Ge}_{\text {sulfide-fluid }}\right)$ between Fe-Zn sulfides (sphalerite +/- pyrite) and the fluids. Isotopically light $\delta^{4 / 70} \mathrm{Ge}$ values of hydrothermal sulfide deposits at EPR $9-10^{\circ} \mathrm{N}$ (down to $-4.71 \%$, Table 3) together with heavy composition of the hydrothermal fluids (average $1.55 \pm 0.36 \%$, 2sd) allows us to estimate $\Delta^{4 / 70} \mathrm{Ge}_{\text {sulfide-fluid }}$ values ranging from -5.17 to $-6.28 \%$ with an average of $-5.6 \pm 0.6 \%$ ( $2 \mathrm{sd}$ ).

Using quantum chemistry calculations, Li et al. (2009) determined $\Delta^{7 / 70} \mathrm{Ge}_{\text {sulfide-Ge(OH)4 }}$ at $25^{\circ} \mathrm{C}$ between -12.2 to $-11.4 \%$ depending on $\mathrm{Ge}$ valence state and coordination (i.e. $\mathrm{Ge}^{\mathrm{II}} \mathrm{S}_{4} \mathrm{Zn}_{2}{ }^{2-}$ and $\mathrm{Ge}^{\mathrm{IV}} \mathrm{S}_{4} \mathrm{Zn}_{2}{ }^{0}$ sulfide species respectively). At Bio9 vent, the precipitation temperature of sphalerite along the chimney wall is generally below $250^{\circ} \mathrm{C}$ (Rouxel et al., 2008). Using the equation $\Delta^{4 / 70} \mathrm{Ge}_{\text {sulfide-fluid }}=\mathrm{A} * 10^{6} /\left(\mathrm{T}^{2}\right)+\mathrm{B}$ and using the reduced isotope partition function ratio reported by Li et al. (2009), we estimate $\Delta^{4 / 70} \mathrm{Ge}_{\text {sulfide-fluid }}$ at $250^{\circ} \mathrm{C}$ for $\mathrm{Ge}^{\mathrm{II}} \mathrm{S}_{4} \mathrm{Zn}_{2}{ }^{2-}$ and $\mathrm{Ge}^{\mathrm{IV}} \mathrm{S}_{4} \mathrm{Zn}_{2}{ }^{0}$ species (i.e. considering $\mathrm{A}=-1.083$ and -1.012 respectively and $\mathrm{B}$ $=0$ as a first approximation). Using this approach, the estimated theoretical $\Delta^{4 / 70} \mathrm{Ge}_{\text {sulfide-fluid }}$ fractionation factors range from -3.97 to $-3.71 \%$, which is consistent with the observed $\mathrm{Ge}$ isotope fractionation factors between hydrothermal fluids and sulfide minerals at Bio9 vent. We notice that differences in Ge redox state or coordination among different sulfide compounds do not drastically change isotope fractionation factors. In contrast, differences of Ge bonding environments such as found in $\mathrm{Ge}-\mathrm{S}$ or $\mathrm{Ge}-\mathrm{O}$ compounds appear to drive the largest isotope fractionation ( $\mathrm{Li}$ et al., 2009).

\subsection{Preliminary Ge-isotope mass balance in seawater}

The average $\mathrm{Ge} / \mathrm{Si}$ ratio in the global ocean is about $0.7 \mu \mathrm{mol} / \mathrm{mol}$ (Froelich and Andreae, 1981) which is significantly lower than the Ge/Si in basaltic rocks of $2.6 \pm 0.3 \times 10^{-6}$ Imol/mol (DeArgollo and Schilling, 1978). Because the two dominant Si and Ge sources to the ocean carry very different $\mathrm{Ge} / \mathrm{Si}$ signatures, with $(\mathrm{Ge} / \mathrm{Si})_{\text {rivers }} \sim 0.4 \mu \mathrm{mol} / \mathrm{mol}$ (Mortlock and 


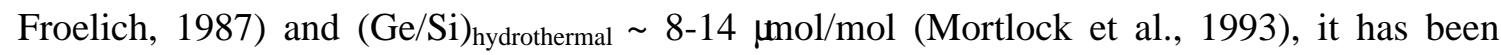
proposed that the Ge/Si ratio buried in biogenic siliceous tests on the seafloor reflects the present and past source strength of the river fluxes relative to hydrothermal fluxes (Elderfield and Schultz, 1996; Froelich et al., 1992; Murnane and Stallard, 1988). However, the use of $\mathrm{Ge} / \mathrm{Si}$ as a paleoceanographic tool remains uncertain as the Ge mass balance in the modern ocean is not well understood. Assuming steady state, the contemporary input fluxes from continents and hydrothermal sources require Ge removal with a Ge/Si ratio of $1.6 \mu \mathrm{mol} / \mathrm{mol}$, which is significantly greater than the observed opal burial ratio of $0.7 \mu \mathrm{mol} / \mathrm{mol}$ (Elderfield and Schultz, 1996). Identification and quantification of the so-called "missing Ge sink" has received great interest in the past decade and it is now proposed that Ge may be removed from the ocean in iron-rich reducing sediments of continental margins independently of $\mathrm{Si}$ (Hammond et al., 2000; King et al., 2000; McManus et al., 2003). This sink corresponds to about $55 \pm 9 \%$ of Ge within opal released by dissolution (Hammond et al., 2000). Considering the potential of $\mathrm{Ge}$ isotopes to fractionate during marine sediment diagenesis, for example during Ge precipitation with authigenic minerals, Ge isotope systematics should be a powerful tool to further constrain the missing sink through the establishment of a mass balance of $\mathrm{Ge}$ isotopes in the oceans.

First, it is important to note that the Ge isotope composition of modern seawater is poorly known. Using the Ge isotope ratios of marine biogenic opal such as sponges, Rouxel et al. (2006) previously suggested that seawater is enriched in heavy Ge isotopes relative to the continental crust by up to $2.5 \%$. However, an unpublished study of the Ge isotope composition of seawater (Baronas et al., 2014) showed that seawater $8^{4 / 70} \mathrm{Ge}$ values range from 3.9 to $3.4 \%$, which is about $3 \%$ heavier than oceanic and continental crust values. The later study confirms a previous report of $\delta^{4 / 70} \mathrm{Ge}$ values of marine diatoms from Holocene sediments at around $3.3 \%$ (Mantoura, 2006). Hence, a value of $3.0 \pm 0.6 \%$ is probably a good estimate of modern seawater $8^{4 / 70} \mathrm{Ge}$ values considering the current knowledge.

Secondly, preliminary investigations of Ge isotope fractionation by marine diatoms revealed that biological uptake of Ge does not fractionate $\delta^{4 / 70} \mathrm{Ge}$ values, in contrast to Si isotopes (Mantoura, 2006). Hence, it can be suggested that seawater $\delta^{4 / 70} \mathrm{Ge}$ values are probably not modified by the biogenic opal sink - and therefore by marine productivity.

With these conditions and considering steady state, the heavy Ge isotope composition of seawater requires either: (1) heavier $\delta^{4 / 70} \mathrm{Ge}$ values for the global Ge input (i.e. rivers and 
hydrothermal vents combined) relative to the continental crust; or (2) a Ge output via the "missing Ge-sink" (e.g. authigenic phases in marine sediments) characterized by lower than crustal $\delta^{4 / 70} \mathrm{Ge}$ values; or (3) a combination of both.

In order to address these issues, we establish a preliminary mass balance of Ge in seawater, using a one box ocean model based on $\mathrm{Ge} / \mathrm{Si}, \delta^{4 / 70} \mathrm{Ge}$ and the marine Ge source and sink fluxes (Table 6). At steady state, the sum of input fluxes and output fluxes of Ge to the ocean are equal:

$$
F_{\text {River }} \dashv F_{\text {Atmospheric }} \dashv F_{\text {Hydrothermal }} \dashv F_{\text {Low-TBasalt }}=F_{\text {Opal }} \dashv F_{\text {Non-Opal }} \text { (Eq. 9) }
$$

With, F, the flux of Ge of each of the inputs and outputs determined based on their Ge/Si ratios and Si fluxes (From Hammond et al., 2000; King et al., 2000; McManus et al., 2003). Considering steady-state conditions, the mass balance of Ge isotopes in seawater is defined as:

$$
\sum_{\text {Source }}\left(F \times \delta^{74} G e\right)=\sum_{\text {sink }}\left(F \times \delta^{74} G e\right)
$$

In order to determine the Ge isotope signature of the missing, non-opal Ge sink, we resolve Eq. 9 and 10 using estimated $\delta^{4 / 70} \mathrm{Ge}$ and $\mathrm{Ge} / \mathrm{Si}$ values of other Ge sinks and sources (Table 6), such as:

(1) $8^{4 / 70} \mathrm{Ge}$ value of atmospheric deposition (i.e. aeolian particles) has been estimated to be identical to crustal values, with $8^{4 / 70} \mathrm{Ge}=0.56 \pm 0.20 \%$ as estimated by Escoube et al. (2012). Si and Ge fluxes from atmospheric deposition were taken from the estimation of King et al. (2000).

(2) Ridge flanks Ge and Si fluxes, including the sum of warm $\left(40-75^{\circ} \mathrm{C}\right)$ hydrothermal systems and low-temperature seafloor basalt weathering were taken from Wheat and McManus (2005). Because of the large range of Ge/Si ratios in warm hydrothermal fluids from ridge flanks, we applied an uncertainty of $50 \%$ to the estimated fluxes (Table 6). $8^{4 / 70} \mathrm{Ge}$ of ridge flank fluxes is also considered similar the average value obtained at Loihi $\left(\delta^{4 / 70} \mathrm{Ge}=1.2 \pm 0.5 \%\right.$ o $)$. Despite the relatively large uncertainties, the ridge flank Ge fluxes have a minor influence on global Ge oceanic cycle due to their small contribution representing less than $10 \%$ of the total Ge input. 
(3) Si and Ge fluxes from rivers were taken from the estimation of King et al. (2000). $\delta^{4 / 70} \mathrm{Ge}$ values of rivers are however presently unknown. As a first approximation, we consider the riverine flux to have a similar $\delta^{4 / 70} \mathrm{Ge}$ value as the average crustal value. Ge/Si in rivers are well known to be fractionated relative to bulk earth (with a ratio around 0.58 $\mu \mathrm{mol} / \mathrm{mol}$ versus $1.3 \mu \mathrm{mol} / \mathrm{mol}$ for the crust, Mortlock and Froelich, 1987). Therefore, the Ge isotope composition of rivers is likely to be fractionated relative to the crust due to $\mathrm{Ge}$ sorption on clay or oxide minerals, as previously observed by Kurtz et al. (2002) and Scribner et al. (2006). Because rivers represent $37 \%$ of the global input of $\mathrm{Ge}$, it is clear that a better constraint on the riverine flux is important for establishing a reliable isotope mass balance in seawater. In order to address this issue, we performed a simple sensitivity test by running our mass balance model using $8^{4 / 70} \mathrm{Ge}$ of rivers identical to either seawater values or average crust values (Table 6).

(4) The $8^{4 / 70} \mathrm{Ge}$ value of the high-temperature (HT) hydrothermal flux is estimated as at $1.55 \pm 0.36 \%$ based on average values obtained from high-temperature vent fluids from EPR. The Ge/Si of the HT hydrothermal flux is determined at $11 \pm 3 \mu \mathrm{mol} / \mathrm{mol}$ based on the compilation of $\mathrm{Ge} / \mathrm{Si}$ values for high-temperature hydrothermal vents presented in Table 2. It should also be recognized that $\mathrm{Ge}$ (and $\mathrm{Si}$ ) fluxes from acidic volcanic island arcs, which represent about $10 \%$ of the hydrothermal flux (Baker et al., 2008), and back arc spreading centers are poorly known. Considering the contrasting chemical composition of hydrothermal fluids in such settings, including high volatile contents (e.g. $\mathrm{SO}_{2}$ ) and low $\mathrm{pH}$ values (Resing et al., 2007; Butterfield et al., 2011; Craddock et al., 2010), it is possible that they contribute differently to Ge and Si fluxes.

(5) The $\delta^{4 / 70} \mathrm{Ge}$ values of the opal sink are considered identical to seawater values as demonstrated in previous studies showing a lack of $\mathrm{Ge} / \mathrm{Si}$ and Ge-isotope fractionation during diatom uptake (Shemesh et al., 1989; Bareille et al., 1998; Mantoura, 2006). Mantoura (2006) reported $8^{4 / 70} \mathrm{Ge}$ values at around $3.3 \%$ for diatom opal from Holocene sediments. These results, together with the lack of Ge isotope fractionation observed during Ge uptake by cultured diatoms (Mantoura 2006) and preliminary Ge isotope measurement of seawater (Baronas et al., 2014) suggest that seawater is enriched in heavy Ge isotopes. In this model, we used a $8^{4 / 70} \mathrm{Ge}$ value of $3.0 \pm 0.6 \%$ o for seawater.

(6) The removal of elements in hydrothermal plume through adsorption onto $\mathrm{FeOOH}$ rich particles is well recognized for seawater oxyanions such as V, As and P (Feely et al., 
$1990,1991)$ but is probably negligible for Ge. In particular, it has been demonstrated that $\mathrm{Ge} /{ }^{3} \mathrm{He}$ ratios of the dispersing hydrothermal plume remain close to high-temperature hydrothermal vent end-member values, suggesting a near conservative behaviour of $\mathrm{Ge}$ during seawater-hydrothermal fluid mixing (Mortlock et al., 1993).

We ran our box model using the parameters defined in Table 6 and by applying an error propagation scheme (i.e. Monte Carlo simulation). We solved simultaneously Eq. 9-10 in order to estimate the $8^{4 / 70} \mathrm{Ge}$ value of the missing, non-opal Ge sink for the cases of (i) riverine input at crustal values and (ii) riverine input identical to seawater values. In the first case, we determined the $8^{4 / 70} \mathrm{Ge}$ value of the non-opal Ge sink to be $-0.6 \pm 0.4 \%$, which is about $3.6 \%$ lighter than seawater. In the second case, we obtained heavier $\delta^{4 / 70} \mathrm{Ge}$ value at $0.9 \pm 0.3 \%$ o for the missing Ge sink, which is about $2.1 \%$ lighter than seawater. These values, albeit different, correspond to the expected isotope fractionation produced by $\mathrm{Ge}$ adsorption onto Fe-oxyhydroxide estimated at $2.0 \%$ on average (this study) and up to $4.4 \%$ o as determined by Pokrovsky et al. (2014). It is however important to note that both the Ge flux estimate and $8^{4 / 70} \mathrm{Ge}$ value of the non-opal Ge sink are highly sensitive to errors in the estimation of global hydrothermal $\mathrm{Ge}$ and $\mathrm{Si}$ fluxes. For example, at the lowest estimate of hydrothermal Si flux, the missing (non-opal) Ge sink becomes insignificant, leading to a very large uncertainty on its $\mathrm{Ge}$ isotope signature.

Based on this simple mass balance, our results suggest that the "missing sink" of Ge in the oceans is likely controlled by the adsorption of $\mathrm{Ge}$ onto Fe-oxyhydroxide in marine sediments as already proposed in previous studies (Hammond et al., 2000; King et al., 2000; McManus et al., 2003). Sulfides are also characterized by very light $\delta^{4 / 70} \mathrm{Ge}$ values (Escoube et al., 2012) which can potentially provide a sink for isotopically light $\mathrm{Ge}$ in the ocean. However, the amount of Ge sequestrated in sedimentary sulfides is probably insignificant compared to the opal and authigenic Fe oxyhydroxide sinks. This assumption is supported by the lack of Ge removal in the sulfidic and anoxic waters of the Baltic Sea (Andreae and Froelich, 1984). The importance of Ge removal with organic matter, however, will need to be further assessed considering the large Ge enrichment factors and the range of Ge isotope compositions in organic-rich rocks and compounds (Li et al., 2009; Li and Liu, 2010).

\section{Synthesis and concluding remarks}


In this study, we applied coupled $\mathrm{Ge} / \mathrm{Si}$ and $8^{4 / 70} \mathrm{Ge}$ as new tracers in seafloor hydrothermal systems with the following systematics (Fig. 4):

(1) Hydrothermal fluid compositions are characterized by a high value of $\mathrm{Ge} / \mathrm{Si}$ ratio and $8^{4 / 70} \mathrm{Ge}$ values, which cannot be fully explained by quartz-controlled solubility of $\mathrm{Si}$ in the reaction zone as the required large fractionation factor $\Delta^{7 / 70} \mathrm{Ge}_{\mathrm{Qz}-\text { fluid }}$ at about $-4.1 \%$ is both unlikely and highly dependent on the Ge/Si fractionation factors (i.e. $\mathrm{K}_{\mathrm{d}}$ values). In this study, we suggested that both quartz and sulfide precipitation in the reaction zone may control $\mathrm{Ge} / \mathrm{Si}$ and Ge-isotope signatures in the fluid.

(2) Subsurface processes such as seawater-fluid mixing and conductive cooling are expected to result in contrasting $\mathrm{Ge} / \mathrm{Si}$ and $\delta^{4 / 70} \mathrm{Ge}$ signatures of the vent fluids. In the case of simple hydrothermal fluid mixing with seawater, no variations of $\mathrm{Ge} / \mathrm{Si}$ and $8^{4 / 70} \mathrm{Ge}$ are expected in the absence of Si-rich mineral precipitation. In some cases, low-temperature fluid circulation in altered basement may induce additional reactions such as: (i) enhanced fluidrock interactions, as is the case at Pohaku vents, leading to a decrease of $\mathrm{Ge} / \mathrm{Si}$ and $\delta^{4 / 70} \mathrm{Ge}$ toward basalt values; (ii) subsurface mineral precipitation and/or redissolution, either as sulfide or/and in Fe-oxyhydroxide and/or amorphous silica may also affect $\mathrm{Ge} / \mathrm{Si}$ and $\mathrm{Ge}$ isotope composition in contrasting ways.

(3) Hydrothermal fluid venting at the seafloor results in extensive precipitation of a variety of Fe and Si phases, including amorphous silica, Fe oxyhydroxide and sulfides. These phases may have specific Ge isotope signatures depending on numerous parameters, such as mineralogy, temperature and attainment of isotopic equilibrium.

Finally, the heavy Ge isotope composition of hydrothermal fluids as observed at Loihi and EPR probably cannot account for the heavy Ge isotope composition of seawater, which is estimated to be $2.4 \%$ heavier compared to the average crust value. Although other major sources of Ge in seawater, such as rivers, need further investigation (e.g. Baronas et al., 2014), our finding suggests that the non-opal Ge sink in seawater is enriched in light $\mathrm{Ge}$ isotopes relative to seawater, which is consistent with Ge sequestration during Fe redox cycling in marine sediments, as suggested by Pokrovsky et al. (2014). Considering the growing interest of using $\mathrm{Ge} / \mathrm{Si}$ and $\mathrm{Si}$-isotope ratios as paleo-environmental proxies in ancient metalliferous deposits such as banded iron formations (Hamade et al., 2003; André et al., 2006; Bekker et al., 2010), Ge isotope ratios may also offer important new constrains to 
determine Ge and Si sources (e.g. hydrothermal vs. continental sources) and sinks in ancient oceans. 


\section{Acknowledgements}

This study was supported by the NSF (FeMO project), Europole Mer (UEB) and ANR-10LABX-19-01. Lary Ball (WHOI), Jurek Blustajn (WHOI), Maureen Auro (WHOI), Emmanuel Ponzevera (IFREMER) and Yoan Germain (IFREMER) are thanked for their technical support. We thank the FeMO team Dave Emerson (Bigelow), Craig Moyer (WWU), Hubert Staudigel (UCSD-SIO), and Brad Tebo (OHSU) for their support and input during cruise operations. We thank the ROV Jason-II pilots and the crews of the R/V Melville, R/V Kilo Moana, and R/V T. Thompson for assistance with deployments and sample collection during the cruises. We thank Albert Galy, Alex Halliday, Philip Pogge von Strandmann, Mark Rehkämper and 3 anonymous reviewers for helpful comments and corrections on the manuscript. RE thanks Alex Halliday for a postdoctoral support (FP7) at the University of Oxford. 


\section{$\underline{\text { References }}$}

André, L., Cardinal, D., Alleman, L.Y. and Moorbath, S. (2006) Silicon isotopes in $~ 3.8 \mathrm{Ga}$ West Greenland rocks as clues to the Eoarchaean supracrustal Si cycle. Earth and Planetary Science Letters 245, 162-173.

Andreae, M.O., Froelich, P.N. (1984) Arsenic, antimony, and germanium biogeochemistry in the Baltic Sea. Tellus Series B-Chemical and Physical Meteorology 36, 101-117.

Arnorsson, S. (1984) Germanium in Icelandic geothermal systems. Geochimica et Cosmochimica Acta 48, 2489-2502.

Azam, F., Hemmingsen, B.B. and Volcani, B.E. (1974) Role of silicon in diatom metabolism. V. Silicic acid transport and metabolism in the heterotrophic diatom Nitzschia alba. Archives of Microbiology 97, 103-114.

Azam, F. and Volcani, B.E. (1981) Germanium-silicon interactions in biological systems. Springer-Verlag, New York.

Bareille, G., Labracherie, M., Mortlock, R.A., Maier-Reimer, E. and Froelich, P.N. (1998) A test of $(\mathrm{Ge} / \mathrm{Si})$ opal as a paleorecorder of $(\mathrm{Ge} / \mathrm{Si})$ Seawater. Geology 26, 179-182.

Baker, E.T., Embley, R.W., Walker, S.L., Resing, J.A., Lupton, J.E., Nakamura, K., de Ronde, C.E.J., Massoth, G.J. (2008). Hydrothermal activity and volcano distribution along the Mariana arc. J. Geophys. Res.-Solid Earth 113, B08S09, doi:10.1029/2007JB005423.

Baronas, J.J., Hammond, D.E., McManus, J., Siebert, C., Wheat, G. (2014) Marine budget for Germanium stable isotopes. Ocean Sciences Meeting, Honolulu, 24-28th February 2014, Abstract ID:13978.

Bekker, A., Slack, J.F., Planavsky, N., Krapež, B., Hofmann, A., Konhauser, K.O., Rouxel, O.J. and Wing, B.A. (2010) Iron Formation: The Sedimentary Product of a Complex Interplay Among Mantle, Tectonic, and Biospheric Processes. Economic Geology 105, 467-508.

Belissont, R., Boiron, M.-C., Luais, B. and Cathelineau, M. (2014) LA-ICP-MS analyses of minor and trace elements and bulk Ge isotopes in zoned Ge-rich sphalerites from the Noailhac - Saint-Salvy deposit (France): Insights into incorporation mechanisms and ore deposition processes. Geochimica et Cosmochimica Acta 126, 518-540.

Bernstein, L.R. (1985) Germanium geochemistry and mineralogy. Geochimica et Cosmochimica Acta 49, 2409-2422.

Butterfield, D.A., Nakamura, K., Takano, B., Lilley, M.D., Lupton, J.E., Resing, J.A., Roe, K.K. (2011) High SO2 flux, sulfur accumulation, and gas fractionation at an erupting submarine volcano. Geology 39, 803-806.

Craddock, P.R., Bach, W., Seewald, J.S., Rouxel, O.J., Reeves, E., Tivey, M.K. (2010) Rare earth element abundances in hydrothermal fluids from the Manus Basin, Papua New Guinea: Indicators of sub-seafloor hydrothermal processes in back-arc basins. Geochimica et Cosmochimica Acta 74, 5494-5513.

De Argollo, R. and Schilling, J.G. (1978) Ge-Si and Ga-Al fractionation in Hawaiian volcanic rocks. Geochimica et Cosmochimica Acta 42, 623-630.

De Carlo, E.H., McMurtry, G.M. and Yeh, H.-W. (1983) Geochemistry of hydrothermal deposits from Loihi submarine volcano, Hawaii. Earth and Planetary Science Letters 66, 438-449.

Edmond, J.M., Measures, C., McDuff, R.E., Chan, L.H., Collier, R., Grant, B., Gordon, L.I. and Corliss, J.B. (1979) Ridge crest hydrothermal activity and the balances of the major and minor elements in the ocean: The Galapagos data. Earth and Planetary Science Letters 46, 1-18. 
Edwards, K.J., Glazer, B.T., Rouxel, O.J., Bach, W., Emerson, D., Davis, R.E., Toner, B.M., Chan, C.S., Tebo, B.M., Staudigel, H. and Moyer, C.L. (2011) Ultra-diffuse hydrothermal venting supports Fe-oxidizing bacteria and massive umber deposition at 5000[thinsp]m off Hawaii. ISME J 5, 1748-1758.

Elderfield, H. and Schultz, A. (1996) Mid-ocean ridge hydrothermal fluxes and the chemical composition of the ocean. Annu. Rev. Earth Planet. Sci. 24, 191-224.

Emerson, D. and Moyer, C.L. (2002) Neutrophilic Fe-oxidizing bacteria are abundant at the Loihi Seamount hydrothermal vents and play a major role in Fe oxide deposition. Applied and Environmental Microbiology 68, 3085-3093.

Emerson, D., Rentz, J.A., Lilburn, T.G., Davis, R.E., Aldrich, H., Chan, C. and Moyer, C.L. (2007) A Novel Lineage of Proteobacteria Involved in Formation of Marine Fe-Oxidizing Microbial Mat Communities. PLoS ONE 2, e667.

Escoube, R., Rouxel, O.J., Luais, B., Ponzevera, E. and Donard, O.F. (2012) An Intercomparison Study of the Germanium Isotope Composition of Geological Reference Materials. Geostandards and Geoanalytical Research 36, 149-159.

Evans, M.J. and Derry, L.A. (2002) Quartz control of high germanium/silicon ratios in geothermal waters. Geology 30, 1019-1022.

Feely, R.A., Massoth, G.J., Baker, E.T., Cowen, J.P., Lamb, M.F., Krogslund, K.A. (1990) The effect of hydrothermal processes on midwater phosphorus distributions in the northeast Pacific. Earth and Planetary Science Letters 96, 305-318.

Feely, R.A., Trefry, J.H., Massoth, G.J., Metz, S. (1991) A comparison of the scavenging of phosphorus and arsenic from seawater by hydrothermal iron oxyhydroxides in the Atlantic and Pacific Oceans. Deep-Sea Research Part a-Oceanographic Research Papers 38, 617623.

Fleming, E.J., Davis, R.E., McAllister, S.M., Chan, C.S., Moyer, C.L., Tebo, B.M. and Emerson, D. (2013) Hidden in plain sight: discovery of sheath-forming, iron-oxidizing Zetaproteobacteria at Loihi Seamount, Hawaii, USA. Fems Microbiology Ecology 85, $116-$ 127.

Fornari, D.J., Shank, T., Von Damm, K.L., Gregg, T.K.P., Lilley, M., Levai, G., Bray, A., Haymon, R.M., Perfit, M.R. and Lutz, R. (1998) Time-series temperature measurements at high-temperature hydrothermal vents, East Pacific Rise 949'-51'N: Evidence for monitoring a crustal cracking event. Earth and Planetary Science Letters 160, 419-431.

Frey, F.A. and Clague, D.A. (1983) Geochemistry of diverse basalt types from Loihi Seamount, Hawaii: petrogenetic implications. Earth Planet. Sci. Lett. 66, 337-355.

Froelich, P.N. and Andreae, M.O. (1981) The marine geochemistry of germanium: Ekasilicon. Science 213, 205-207.

Froelich, P.N., Blanc, V., Mortlock, R.A., Chillrud, S.N., Dunstan, W., A., U. and Peng, T.-H. (1992) River fluxes of dissolved silica to the ocean were higher during glacials: $\mathrm{Ge} / \mathrm{Si}$ in diatoms, rivers, and oceans. Paleoceanography 7, 739-767.

Froelich, P.N., Hambrick, G.A., Andreae, M.O., Mortlock, R.A. and Edmond, J.M. (1985a) The geochemistry of germanium in natural waters. J. Geophys. Res. 90, 1133-1141.

Froelich, P.N., Hambrick, G.A., Kaul, L.W., Byrd, J.T. and Lecointe, O. (1985b) Geochemical behavior of inorganic germanium in an unperturbed estuary. Geochimica et Cosmochimica Acta 49, 519-524.

Froelich, P.N., Mortlock, R.A. and Shemesh, A. (1989) Inorganic germanium and silica in the Indian Ocean: biological fractionation during (Ge/Si)Opal formation. Global Biogeochemical Cycles 3, 79-88.

Glazer, B.T. and Rouxel, O.J. (2009) Redox speciation and distribution within diverse Irondominated microbial habitats at Loihi Seamount. Geomicrobiology Journal 26, 606-622. 
Haddad, A.G., Fakra, S.C., Orcutt, B.N., Toner, B.M., Chan, C.S., Rouxel, O.J. and Edwards, K.J. (in prep) Preservation of biogenic Fe oxyhydroxides in microbial mats at Loihi Seamount, Hawaii. submitted to Geochim Cosmochim Acta.

Halicz, L. (1985) Determination of germanium in silicate rocks and sulphide ores by hydride generation and flame atomic-absorption spectrophotometry. The Analyst 110, 943-946.

Hamade, T., Konhauser, K.O., Raiswell, R., Goldsmith, S. and Morris, R.C. (2003) Using $\mathrm{Ge} / \mathrm{Si}$ ratios to decouple iron and silica fluxes in Precambrian banded iron fomations. Geology 31, 35-38.

Hammond, D.E., McManus, J., Berelson, W.M., Meredith, C., Klinkhammer, G.P. and Coale, K.H. (2000) Diagenetic fractionation of Ge and Si in reducing sediments: the missing Ge sink and a possible mechanism to cause glacial/interglacial variations in oceanic $\mathrm{Ge} / \mathrm{Si}$. Geochimica et Cosmochimica Acta 64, 2453-2465.

Haymon, R.M., Fornari, D.J., Von Damm, K.L., Lilley, M.D., Perfit, M.R., Edmond, J.M., Shanks Iii, W.C., Lutz, R.A., Grebmeier, J.M., Carbotte, S., Wright, D., McLaughlin, E., Smith, M., Beedle, N. and Olson, E. (1993) Volcanic eruption of the mid-ocean ridge along the East Pacific Rise crest at $9^{\circ} 45-52^{\prime} \mathrm{N}$ : Direct submersible observations of seafloor phenomena associated with an eruption event in April, 1991. Earth and Planetary Science Letters 119, 85-101.

John, S.G., Rouxel, O.J., Craddock, P.R., Engwall, A.M. and Boyle, E.A. (2008) Zinc stable isotopes in seafloor hydrothermal vent fluids and chimneys. Earth and Planetary Science Letters 269, 17-28.

Karl, D.M., McMurtry, G.M., Malahoff, A. and Garcia, M.O. (1988) Loihi Seamount, Hawaii: A mid-plate volcano with a distinctive hydrothermal system. Nature 335, 532-535.

King, S.L., Froelich, P.N. and Jahnke, R.A. (2000) Early diagenesis of germanium in sediments of the Antarctic South Atlantic: in search of the missing Ge sink. Geochimica et Cosmochimica Acta 64, 1375-1390.

Kurtz, A.C., Derry, L.A. and Chadwick, O.A. (2002) Germanium-silicon fractionation in the weathering environment. Geochimica et Cosmochimica Acta 66, 1525-1537.

Lewin, J.C. (1966) Silicon metabolism in diatoms. V. Germanium dioxide, a specific inhibitor of diatom growth. Phyeologia 6, 1-12

Li, X., Zhao, H., Tang, M. and Liu, Y. (2009) Theoretical prediction for several important equilibrium $\mathrm{Ge}$ isotope fractionation factors and geological implications. Earth and Planetary Science Letters 287, 1-11.

Li, X.F. and Liu, Y. (2010) First-principles study of Ge isotope fractionation during adsorption onto Fe(III)-oxyhydroxides surfaces. Chemical Geology 278, 15-22.

Mantoura, S.C. (2006) Development and Application of Opal based Paleoceanographic Proxies. Unpublished Ph.D thesis, Univ of Cambridge, England, 218pp.

McManus, J., Hammond, D.E., Cummins, K., Klinkhammer, G.P. and Berelson, W.M. (2003) Diagenetic Ge-Si fractionation in continental margin environments: further evidence for a nonopal Ge sink. Geochimica et Cosmochimica Acta 67, 4545-4557.

Mortlock, R.A. and Froelich, P.N. (1986) Hydrothermal germanium over the Southern East Pacific Rise. Science 231, 43-45.

Mortlock, R.A. and Froelich, P.N. (1987) Continental weathering of germanium: Ge/Si in the global river discharge. Geochimica et Cosmochimica Acta 51, 2075-2082.

Mortlock, R.A. and Froelich, P.N. (1996) Determination of germanium by isotope dilutionhydride generation inductively coupled plasma mass spectrometry. Analytica Chimica Acta 332, 277-284.

Mortlock, R.A., Froelich, P.N., Feely, R.A., Massoth, G.J., Butterfield, D.A. and Lupton, J.E. (1993) Silica and germanium in Pacific Ocean hydrothermal vents and plumes. Earth and Planetary Science Letters 119, 365-378. 
Mottl, M.J. (1983) Metabasalts, axial hot springs, and the structure of hydrothermal systems at mid-ocean ridges. Geological Society of America Bulletin 94, 161-180.

Murnane, R.J. and Stallard, R.F. (1988) Germanium/silicon fractionation during biogenic opal formation. Paleoceanography 3, 461-469.

Murnane, R.J. and Stallard, R.F. (1990) Germanium and silicon in rivers of the Orinoco drainage basin. Nature 344, 749-752.

Pokrovski, G.S., Roux, J., Hazemann, J.-L. and Testemale, D. (2005) An X-ray absorption spectroscopy study of argutite solubility and aqueous Ge(IV) speciation in hydrothermal fluids to 500 [degree sign]C and 400 bar. Chemical Geology 217, 127-145.

Pokrovski, G.S. and Schott, J. (1998) Thermodynamic properties of aqueous Ge(IV) hydroxide complexes from 25 to 350[degree sign]C: Implications for the behavior of germanium and the Ge/Si ratio in hydrothermal fluids. Geochimica et Cosmochimica Acta 62, 1631-1642.

Pokrovsky, O.S., Galy, A., Schott, J., Pokrovski, G.S. and Mantoura, S. (2014) Germanium isotope fractionation during $\mathrm{Ge}$ adsorption on goethite and its coprecipitation with $\mathrm{Fe}$ oxy(hydr)oxides. Geochimica et Cosmochimica Acta 131, 138-149.

Pokrovsky, O.S., Pokrovski, G.S., Schott, J. and Galy, A. (2006) Experimental study of germanium adsorption on goethite and germanium coprecipitation with iron hydroxide: $\mathrm{X}$ ray absorption fine structure and macroscopic characterization. Geochimica et Cosmochimica Acta 70, 3325-3341.

Qi, H.-W., Rouxel, O., Hu, R.-Z., Bi, X.-W. and Wen, H.-J. (2011) Germanium isotopic systematics in Ge-rich coal from the Lincang Ge deposit, Yunnan, Southwestern China. Chemical Geology 286, 252-265.

Resing, J.A., Lebon, G., Baker, E.T., Lupton, J.E., Embley, R.W., Massoth, G.J., Chadwick, W.W., De Ronde, C.E.J. (2007) Venting of acid-sulfate fluids in a high-sulfidation setting at NW rota-1 submarine volcano on the mariana arc. Economic Geology 102: 1047-1061.

Rouxel, O., Galy, A. and Elderfield, H. (2006) Germanium isotopic variations in igneous rocks and marine sediments. Geochimica et Cosmochimica Acta 70, 3387-3400.

Rouxel, O., Shanks Iii, W.C., Bach, W. and Edwards, K.J. (2008) Integrated Fe- and Sisotope study of seafloor hydrothermal vents at East Pacific Rise $9-10^{\circ} \mathrm{N}$. Chemical Geology 252, 214-227.

Scribner, A.M., Kurtz, A.C., Chadwick, O.A. (2006) Germanium sequestration by soil: Targeting the roles of secondary clays and Fe-oxyhydroxides. Earth and Planetary Science Letters 243, 760-770.

Sedwick, P.N., McMurtry, G.M. and Macdougall, J.D. (1992) Chemistry of hydrothermal solutions from Pele's Vents, Loihi Seamount, Hawaii. Geochimica et Cosmochimica Acta 56, 3643-3667.

Shank, T.M., Fornari, D.J., Von Damm, K.L., Lilley, M.D., Haymon, R.M. and Lutz, R.A. (1998) Temporal and spatial patterns of biological community development at nascent deep-sea hydrothermal vents $\left(9^{\circ} 50^{\prime} \mathrm{N}\right.$, East Pacific Rise). Deep-Sea Research Part II: Topical Studies in Oceanography 45, 465-515.

Shemesh, A., Mortlock, R.A. and Froelich, P.N. (1989) Late Cenozoic Ge/Si record of marine biogenic opal: implications for variations of riverine fluxes to the ocean. Paleoceanography 4, 221-234.

Siebert, C., Hammond, D.E., Ross, A. and McManus, J. (2011) Erratum to C. Siebert, A. Ross and J. McManus (2006), "Germanium isotope measurements of high-temperature geothermal fluids using double-spike hydride generation MC-ICP-MS", Geochimica et Cosmochimica Acta 70, 3986-3995. Geochimica et Cosmochimica Acta 75, 6267-6269. 
Siebert, C., Ross, A. and McManus, J. (2006) Germanium isotope measurements of hightemperature geothermal fluids using double-spike hydride generation MC-ICP-MS. Geochimica et Cosmochimica Acta 70, 3986-3995.

Stein, C.A. and Stein, S. (1994) Constraints on hydrothermal heat flux through the oceanic lithosphere from global heat flow. Journal of Geophysical Research 99, 3081-3095.

Tivey, M.K. (1995) The influence of hydrothermal fluid composition and advection rates on black smoker chimney mineralogy: Insights from modeling transport and reaction. Geochimica et Cosmochimica Acta 59, 1933-1949.

Toner, B.M., Berquó, T.S., Michel, F.M., Sorensen, J.V., Templeton, A.S. and Edwards, K.J. (2012) Mineralogy of iron microbial mats from Loihi Seamount. Frontiers in Microbiology 3.

Von Damm, K.L. (2000) Chemistry of hydrothermal vent fluids from $9^{\circ}-10^{\circ} \mathrm{N}$, East Pacific Rise: "Time zero," the immediate posteruptive period. Journal of Geophysical Research B: Solid Earth 105, 11203-11222.

Von Damm, K.L. (2004) Evolution of the hydrothermal system at East Pacific Rise 9'50N: geochemical evidence for changes in the upper oceanic crust. W.S.D. Wilcock, E.F. DeLong, D.S. Kelley, J.A. Baross, S.C. Cary (Eds.), The Subsurface Biosphere at Midocean Ridges, AGU Monograph 144

Von Damm, K.L., Bischoff, J.L. and Rosenbauer, R.J. (1991) Quartz solubility in hydrothermal seawater: an experimental study and equation describing quartz solubility for up to $0.5 \mathrm{M} \mathrm{NaCl}$ solutions. American Journal of Science 291, 977-1007.

Von Damm, K.L., Edmond, J.M., Grant, B., Measures, C.I., Walden, B. and Weiss, R.F. (1985) Chemistry of submarine hydrothermal solutions at $21^{\circ} \mathrm{N}$, East Pacific Rise. Geochimica et Cosmochimica Acta 49, 2197-2220.

Wheat, C.G., Jannasch, H.W., Plant, J.N., Moyer, C.L., Sansone, F.J. and McMurtry, G.M. (2000) Continuous sampling of hydrothermal fluids from Loihi Seamount after the 1996 event. Journal of Geophysical Research B: Solid Earth 105, 19353-19367.

Wheat, C.G. and McManus, J. (2005) The potential role of ridge-flank hydrothermal systems on oceanic germanium and silicon balances. Geochimica et Cosmochimica Acta 69, 20212029.

Wheat, C.G. and McManus, J. (2008) Germanium in mid-ocean ridge flank hydrothermal fluids. Geochemistry, Geophysics, Geosystems 9.

Wheat, C.G., Mottl, M.J., Fisher, A.T., Kadko, D., Davis, E.E. and Baker, E. (2004) Heat flow through a basaltic outcrop on a sedimented young ridge flank. Geochemistry, Geophysics, Geosystems 5.

Wheat, C.G., Mottl, M.J. and Rudnicki, M. (2002) Trace element and REE composition of a low-temperature ridge-flank hydrothermal spring. Geochimica et Cosmochimica Acta 66, 3693-3705. 


\section{Figures}

Fig. 1: Multibeam bathymetric map of the summit of Loihi Seamount. Contour interval corresponds to $10 \mathrm{~m}$ and grid size is $350 \mathrm{~m}$. Active hydrothermal sites investigated in this study are shown, including Pele's Pit vents (Spillway Area: M34 and M38) and Hiolo Area (M36 and M39), Lohiau Area (M2 and M5), and Pohaku Area (M57).

Fig. 2: Chemistry of Loihi hydrothermal fluids: (a) relationship between $\mathrm{Si}(\mu \mathrm{M})$ and $\mathrm{Ge}$ $(\mathrm{nM})$ for Pele's Pit vents (including Lohiau) showing a linear regression with $\mathrm{r}^{2}=0.911$ and characterized by $\mathrm{Ge} / \mathrm{Si}$ of about $31.3 \mathrm{\mu mol} / \mathrm{mol}$; (b) Ge/Si versus Fe/Mn ratios showing larger variability in vent fluid composition for M57 and M5 relative to Pele's Pit vents; (c) Fe versus $\mathrm{Mn}$ and (d) Si versus $\mathrm{Mn}$ contents showing that $\mathrm{Fe}, \mathrm{Mn}$ and Si concentrations are mainly controlled by dilution of the vent fluids with seawater.

Fig. 3: Ge-isotope composition $\left(8^{4 / 70} \mathrm{Ge}\right)$ of the low-temperature $\left(21-55^{\circ} \mathrm{C}\right)$ hydrothermal fluids and Fe-rich deposits at Loihi Seamount. Data for Pele's Pit area (markers M34, M36, M38, M39), Lohiau area (markers M2 and M5) and Pohaku (marker M57) are represented with different symbols. For comparison, data for basalt and seawater are also presented. Average basalt value is from Rouxel et al. (2006) after normalization relative to NIST3120a standard as presented in Escoube et al. (2012). Seawater with a $8^{4 / 70} \mathrm{Ge}$ value of $3.0 \pm 0.6 \%$ o has been estimated from the preliminary measurements of Baronas et al. (2014) and based on biogenic silica (Rouxel et al., 2006 and Mantoura, 2006). Error bars represent $2 \mathrm{sd}$.

Fig. 4: Schematic diagram representing the behaviour of Ge-tracers $\left(\mathrm{Ge} / \mathrm{Si}\right.$ and $\left.8^{4 / 70} \mathrm{Ge}\right)$ in the hydrothermal system at Loihi. The diagram shows $\mathrm{Ge} / \mathrm{Si}$ and $8^{4 / 70} \mathrm{Ge}$ signatures of the different hydrothermal sites investigated (Pele's Pit, Lohiau, Pohaku). This model considers the presence of a high temperature reaction zone with $\mathrm{Ge} / \mathrm{Si}$ and $8^{4 / 70} \mathrm{Ge}$ signatures being similar to the high temperature (HT) hydrothermal fluid end-members measured at East Pacific Rise at $9^{\circ} 50^{\prime} \mathrm{N}$ (this study). 


\section{$\underline{\text { Tables }}$}

Table 1: Chemical and Ge isotopic composition of hydrothermal fluids at Loihi Seamount and East Pacific Rise at $9^{\circ} 50^{\prime} \mathrm{N}$.

Table 2: Geochemical and Ge isotopic composition of Fe-rich deposits at Loihi Seamount.

Table 3: Chemical composition and sample description of mineral (mar: marcasite; py: pyrite; sph: sphalerite) separates of active and inactive sulfide deposits from East Pacific Rise (EPR) at $9-10^{\circ} \mathrm{N}$.

Table 4: Summary of Ge/Si and $8^{4 / 70} \mathrm{Ge}$ ratios measured in seafloor hydrothermal fluids.

Table 5: Determination of Ge distribution among the different phases of Fe-rich deposits at Loihi and estimation of the $\mathrm{Ge}$ isotope fractionation factor between Fe-oxyhydroxides $(\mathrm{FeOOH})$ and hydrothermal fluid.

Table 6: Global Si and Ge fluxes in the modern ocean, and their Ge/Si and Ge isotope signatures. 
Table 1: Chemical and Ge isotopic composition of hydrothermal fluids at Loihi Seamount and East Pacific Rise at 9 ${ }^{\circ} 50^{\prime} \mathrm{N}$.

\begin{tabular}{|c|c|c|c|c|c|c|c|c|c|c|c|c|c|c|}
\hline $\begin{array}{l}\text { Sampl } \\
\text { e } \\
\text { Name }\end{array}$ & $\begin{array}{l}\text { Mar } \\
\text { ker }\end{array}$ & $\begin{array}{l}Y \\
\text { ea } \\
r\end{array}$ & $\begin{array}{l}\text { Te } \\
\mathrm{mp}\end{array}$ & $\begin{array}{l}\mathrm{p} \\
\mathrm{H}\end{array}$ & $\begin{array}{l}\text { Alk } \\
\text { (a) }\end{array}$ & $\begin{array}{l}\text { C } \\
a \\
\text { (a }\end{array}$ & $\begin{array}{l}\mathrm{Fe} \\
\text { (a) }\end{array}$ & $\begin{array}{l}M \\
n \\
\text { (a) }\end{array}$ & $\begin{array}{l}\mathrm{Si} \\
\text { (b) }\end{array}$ & $\begin{array}{l}\mathrm{Ge} \\
\text { (c) }\end{array}$ & $\begin{array}{l}\mathrm{Fe} / \\
\mathrm{Mn}\end{array}$ & $\begin{array}{l}\mathrm{Ge} / \\
\mathrm{Si}\end{array}$ & $\begin{array}{l}8^{8 / 70} \\
\mathrm{Ge}\end{array}$ & $\begin{array}{l}2 s \\
d\end{array}$ \\
\hline & & & ${ }^{\circ} \mathrm{C}$ & & $\begin{array}{l}\mathrm{me} \\
\mathrm{q} / \mathrm{k} \\
\mathrm{g}\end{array}$ & $\begin{array}{l}\mathrm{m} \\
\mathrm{M}\end{array}$ & $\mu \mathrm{M}$ & $\mu \mathrm{M}$ & $\mu \mathrm{M}$ & $\begin{array}{l}\mathrm{n} \\
\mathrm{M}\end{array}$ & $\begin{array}{l}\mathrm{mol} / \\
\mathrm{mol}\end{array}$ & $\begin{array}{l}\mu \mathrm{mol} \\
/ \mathrm{mol}\end{array}$ & $\begin{array}{l}\text { NIST } \\
3120 \\
a\end{array}$ & \\
\hline $\begin{array}{l}\frac{\text { Pele's }}{\text { Pit },} \\
\frac{\text { Spillw }}{\text { ay }} \\
\frac{\text { Area }}{\text { (M34 }} \\
\text { \& 38) }\end{array}$ & & & & & & & & & & & & & & \\
\hline $\begin{array}{l}\overline{J 2-} \\
\text { 308- } \\
\text { MS3- } \\
\text { RL }\end{array}$ & $\begin{array}{l}\text { M3 } \\
4\end{array}$ & $\begin{array}{l}20 \\
07\end{array}$ & $\begin{array}{l}47 . \\
0\end{array}$ & $\begin{array}{l}6 . \\
7 \\
2\end{array}$ & $\begin{array}{l}12 . \\
8\end{array}$ & $\begin{array}{l}1 \\
7 . \\
1\end{array}$ & $\begin{array}{l}354 \\
.7\end{array}$ & $\begin{array}{l}12 \\
.3\end{array}$ & $\begin{array}{l}25 \\
99\end{array}$ & $\begin{array}{l}83 \\
.1\end{array}$ & $\begin{array}{l}28 . \\
9\end{array}$ & 32.0 & 2.09 & $\begin{array}{l}0 . \\
1 \\
1\end{array}$ \\
\hline $\begin{array}{l}\text { J2- } \\
\text { 308- } \\
\text { MS4- } \\
\text { RR }\end{array}$ & $\begin{array}{l}\mathrm{M} 3 \\
4\end{array}$ & $\begin{array}{l}20 \\
07\end{array}$ & $\begin{array}{l}47 . \\
0\end{array}$ & $\begin{array}{l}6 . \\
5 \\
4\end{array}$ & $\begin{array}{l}12 . \\
8\end{array}$ & $\begin{array}{l}1 \\
6 . \\
6\end{array}$ & $\begin{array}{l}333 \\
.2\end{array}$ & $\begin{array}{l}11 \\
.6\end{array}$ & $\begin{array}{l}24 \\
64\end{array}$ & $\begin{array}{l}81 \\
.0\end{array}$ & $\begin{array}{l}28 . \\
7\end{array}$ & 32.8 & 2.08 & $\begin{array}{l}0 . \\
1 \\
1\end{array}$ \\
\hline $\begin{array}{l}\text { J2- } \\
241- \\
\text { MS3 }\end{array}$ & $\begin{array}{l}\text { M3 } \\
4\end{array}$ & $\begin{array}{l}20 \\
06\end{array}$ & $\begin{array}{l}54 . \\
0\end{array}$ & $\begin{array}{l}6 . \\
3 \\
7\end{array}$ & $\begin{array}{l}20 . \\
6\end{array}$ & $\begin{array}{l}2 \\
2 . \\
2\end{array}$ & $\begin{array}{l}690 \\
.2\end{array}$ & $\begin{array}{l}18 \\
.1\end{array}$ & $\begin{array}{l}46 \\
64\end{array}$ & $\begin{array}{l}15 \\
2 . \\
8\end{array}$ & $\begin{array}{l}38 . \\
2\end{array}$ & 32.8 & 1.99 & $\begin{array}{l}0 . \\
1 \\
1\end{array}$ \\
\hline $\begin{array}{l}\text { J2- } \\
241- \\
\text { MS4 }\end{array}$ & $\begin{array}{l}\mathrm{M} 3 \\
4\end{array}$ & $\begin{array}{l}20 \\
06\end{array}$ & $\begin{array}{l}54 . \\
0\end{array}$ & $\begin{array}{l}6 . \\
0 \\
2\end{array}$ & $\begin{array}{l}21 . \\
2\end{array}$ & $\begin{array}{l}2 \\
2 . \\
4\end{array}$ & $\begin{array}{l}726 \\
.7\end{array}$ & $\begin{array}{l}18 \\
.1\end{array}$ & $\begin{array}{l}44 \\
64\end{array}$ & $\begin{array}{l}17 \\
7 . \\
2\end{array}$ & $\begin{array}{l}40 . \\
1\end{array}$ & 39.7 & 1.55 & $\begin{array}{l}0 . \\
1 \\
1\end{array}$ \\
\hline $\begin{array}{l}\text { J2- } \\
245- \\
\text { MS4 }\end{array}$ & $\begin{array}{l}\mathrm{M} 3 \\
4\end{array}$ & $\begin{array}{l}20 \\
06\end{array}$ & $\begin{array}{l}52 . \\
0\end{array}$ & $\begin{array}{l}6 . \\
0 \\
0\end{array}$ & $\begin{array}{l}21 . \\
6\end{array}$ & $\begin{array}{l}2 \\
1 . \\
6\end{array}$ & $\begin{array}{l}609 \\
.9\end{array}$ & $\begin{array}{l}17 \\
.0\end{array}$ & $\begin{array}{l}42 \\
26\end{array}$ & $\begin{array}{l}15 \\
1 . \\
1\end{array}$ & $\begin{array}{l}35 . \\
9\end{array}$ & 35.7 & 1.77 & $\begin{array}{l}0 . \\
1 \\
1\end{array}$ \\
\hline $\begin{array}{l}\mathrm{J} 2- \\
315- \\
\mathrm{MS}- \\
\mathrm{RL}\end{array}$ & $\begin{array}{l}\text { M3 } \\
8\end{array}$ & $\begin{array}{l}20 \\
07\end{array}$ & $\begin{array}{l}47 . \\
0\end{array}$ & $\begin{array}{l}6 . \\
9 \\
6\end{array}$ & 8.1 & $\begin{array}{l}1 \\
7 . \\
7\end{array}$ & $\begin{array}{l}419 \\
.0\end{array}$ & $\begin{array}{l}14 \\
.5\end{array}$ & $\begin{array}{l}30 \\
96\end{array}$ & $\begin{array}{l}93 \\
.4\end{array}$ & $\begin{array}{l}28 . \\
8\end{array}$ & 30.2 & 2.20 & $\begin{array}{l}0 . \\
1 \\
1\end{array}$ \\
\hline $\begin{array}{l}\mathrm{J} 2- \\
315- \\
\text { MS- } \\
\text { RR }\end{array}$ & $\begin{array}{l}\text { M3 } \\
8\end{array}$ & $\begin{array}{l}20 \\
07\end{array}$ & $\begin{array}{l}47 . \\
0\end{array}$ & & & $\begin{array}{l}1 \\
6 . \\
6\end{array}$ & $\begin{array}{l}426 \\
.6\end{array}$ & $\begin{array}{l}15 \\
.2\end{array}$ & $\begin{array}{l}31 \\
29\end{array}$ & $\begin{array}{l}96 \\
.3\end{array}$ & $\begin{array}{l}28 . \\
1\end{array}$ & 30.8 & 1.97 & $\begin{array}{l}0 . \\
1 \\
1\end{array}$ \\
\hline $\begin{array}{l}\text { J2- } \\
\text { 314- } \\
\text { MS- } \\
\text { RL }\end{array}$ & $\begin{array}{l}\mathrm{M3} \\
8\end{array}$ & $\begin{array}{l}20 \\
07\end{array}$ & $\begin{array}{l}55 . \\
0\end{array}$ & $\begin{array}{l}6 . \\
2 \\
1\end{array}$ & $\begin{array}{l}12 . \\
3\end{array}$ & $\begin{array}{l}1 \\
6 . \\
0\end{array}$ & $\begin{array}{l}303 \\
.9\end{array}$ & $\begin{array}{l}10 \\
.6\end{array}$ & $\begin{array}{l}23 \\
60\end{array}$ & $\begin{array}{l}73 \\
.3\end{array}$ & $\begin{array}{l}28 . \\
6\end{array}$ & 31.1 & 2.17 & $\begin{array}{l}0 . \\
1 \\
1\end{array}$ \\
\hline $\begin{array}{l}\text { J2- } \\
\text { 314- } \\
\text { MS- } \\
\text { RR }\end{array}$ & $\begin{array}{l}\text { M3 } \\
8\end{array}$ & $\begin{array}{l}20 \\
07\end{array}$ & $\begin{array}{l}55 . \\
0\end{array}$ & $\begin{array}{l}6 . \\
1 \\
0\end{array}$ & $\begin{array}{l}10 . \\
2\end{array}$ & $\begin{array}{l}1 \\
4 . \\
7\end{array}$ & $\begin{array}{l}234 \\
.2\end{array}$ & $\begin{array}{l}8 . \\
1\end{array}$ & $\begin{array}{l}18 \\
40\end{array}$ & $\begin{array}{l}54 \\
.6\end{array}$ & $\begin{array}{l}28 . \\
8\end{array}$ & 29.7 & 1.89 & $\begin{array}{l}0 . \\
1 \\
1\end{array}$ \\
\hline
\end{tabular}




\begin{tabular}{|c|c|c|c|c|c|c|c|c|c|c|c|c|c|c|}
\hline $\begin{array}{l}\frac{\text { Pele's }}{\text { Pit, }} \\
\frac{\text { Hiolo }}{\text { area }} \\
\frac{\text { (M36 }}{\text { \& 39) }}\end{array}$ & & & & & & & & & & & & & & \\
\hline $\begin{array}{l}\overline{J 2-} \\
314- \\
\text { MS- } \\
\text { BL }\end{array}$ & $\begin{array}{l}\text { M3 } \\
6\end{array}$ & $\begin{array}{l}20 \\
07\end{array}$ & $\begin{array}{l}50 . \\
0\end{array}$ & $\begin{array}{l}6 . \\
2 \\
9\end{array}$ & $\begin{array}{l}10 . \\
2\end{array}$ & $\begin{array}{l}1 \\
5 . \\
1\end{array}$ & $\begin{array}{l}338 \\
.1\end{array}$ & $\begin{array}{l}15 \\
.3\end{array}$ & $\begin{array}{l}26 \\
04\end{array}$ & $\begin{array}{l}74 \\
.6\end{array}$ & $\begin{array}{l}22 . \\
1\end{array}$ & 28.7 & 1.50 & \\
\hline $\begin{array}{l}\text { J2- } \\
314- \\
\text { MS- } \\
\text { BR }\end{array}$ & $\begin{array}{l}\text { M3 } \\
6\end{array}$ & $\begin{array}{l}20 \\
07\end{array}$ & $\begin{array}{l}50 . \\
0\end{array}$ & $\begin{array}{l}5 . \\
8 \\
4\end{array}$ & $\begin{array}{l}11 . \\
7\end{array}$ & $\begin{array}{l}1 \\
5 . \\
6\end{array}$ & $\begin{array}{l}397 \\
.6\end{array}$ & $\begin{array}{l}17 \\
.8\end{array}$ & $\begin{array}{l}30 \\
06\end{array}$ & $\begin{array}{l}88 \\
.9\end{array}$ & $\begin{array}{l}22 . \\
4\end{array}$ & 29.6 & 1.77 & $\begin{array}{l}0 . \\
1 \\
1\end{array}$ \\
\hline $\begin{array}{l}\text { J2- } \\
241- \\
\text { MS1 }\end{array}$ & $\begin{array}{l}\text { M3 } \\
6\end{array}$ & $\begin{array}{l}20 \\
06\end{array}$ & $\begin{array}{l}51 . \\
0\end{array}$ & $\begin{array}{l}6 . \\
0 \\
1\end{array}$ & $\begin{array}{l}12 . \\
9\end{array}$ & $\begin{array}{l}1 \\
7 . \\
4\end{array}$ & $\begin{array}{l}557 \\
.8\end{array}$ & $\begin{array}{l}23 \\
.4\end{array}$ & $\begin{array}{l}27 \\
82\end{array}$ & $\begin{array}{l}11 \\
3 . \\
5\end{array}$ & $\begin{array}{l}23 . \\
9\end{array}$ & 40.8 & 1.35 & $\begin{array}{l}0 . \\
1 \\
1\end{array}$ \\
\hline $\begin{array}{l}\mathrm{J} 2- \\
242- \\
\text { MS2 }\end{array}$ & $\begin{array}{l}\text { M3 } \\
6\end{array}$ & $\begin{array}{l}20 \\
06\end{array}$ & $\begin{array}{l}51 . \\
0\end{array}$ & $\begin{array}{l}5 . \\
7 \\
6\end{array}$ & $\begin{array}{l}12 . \\
9\end{array}$ & $\begin{array}{l}1 \\
7 . \\
6\end{array}$ & $\begin{array}{l}552 \\
.3\end{array}$ & $\begin{array}{l}23 \\
.8\end{array}$ & $\begin{array}{l}29 \\
66\end{array}$ & $\begin{array}{l}82 \\
.4\end{array}$ & $\begin{array}{l}23 . \\
2\end{array}$ & 27.8 & 1.07 & $\begin{array}{l}0 . \\
1 \\
1\end{array}$ \\
\hline $\begin{array}{l}\text { J2- } \\
308- \\
\text { MS1- } \\
\text { BL }\end{array}$ & $\begin{array}{l}\text { M3 } \\
9\end{array}$ & $\begin{array}{l}20 \\
07\end{array}$ & $\begin{array}{l}45 . \\
0\end{array}$ & $\begin{array}{l}6 . \\
6 \\
7\end{array}$ & $\begin{array}{l}14 . \\
7\end{array}$ & $\begin{array}{l}1 \\
8 . \\
7\end{array}$ & $\begin{array}{l}576 \\
.0\end{array}$ & $\begin{array}{l}24 \\
.1\end{array}$ & $\begin{array}{l}40 \\
69\end{array}$ & $\begin{array}{l}11 \\
6 . \\
0\end{array}$ & $\begin{array}{l}23 . \\
9\end{array}$ & 28.5 & 1.60 & $\begin{array}{l}0 . \\
1 \\
1\end{array}$ \\
\hline $\begin{array}{l}\text { J2- } \\
308- \\
\text { MS2- } \\
\text { BR }\end{array}$ & $\begin{array}{l}\text { M3 } \\
9\end{array}$ & $\begin{array}{l}20 \\
07\end{array}$ & $\begin{array}{l}45 . \\
0\end{array}$ & $\begin{array}{l}6 . \\
6 \\
9\end{array}$ & $\begin{array}{l}14 . \\
8\end{array}$ & $\begin{array}{l}1 \\
8 . \\
7\end{array}$ & $\begin{array}{l}577 \\
.8\end{array}$ & \begin{tabular}{|l|}
24 \\
.5
\end{tabular} & $\begin{array}{l}41 \\
31\end{array}$ & $\begin{array}{l}11 \\
9 . \\
5\end{array}$ & $\begin{array}{l}23 . \\
6\end{array}$ & 28.9 & 1.74 & $\begin{array}{l}0 . \\
1 \\
1\end{array}$ \\
\hline $\begin{array}{l}\text { J2- } \\
311- \\
\text { MS- } \\
\text { BL }\end{array}$ & $\begin{array}{l}\text { M3 } \\
9\end{array}$ & $\begin{array}{l}20 \\
07\end{array}$ & $\begin{array}{l}47 . \\
4\end{array}$ & $\begin{array}{l}6 . \\
2 \\
9\end{array}$ & 8.1 & $\begin{array}{l}1 \\
3 . \\
9\end{array}$ & $\begin{array}{l}261 \\
.4\end{array}$ & $\begin{array}{l}11 \\
.5\end{array}$ & $\begin{array}{l}17 \\
72\end{array}$ & $\begin{array}{l}48 \\
.1\end{array}$ & $\begin{array}{l}22 . \\
8\end{array}$ & 27.2 & 1.39 & $\begin{array}{l}0 . \\
1 \\
1\end{array}$ \\
\hline $\begin{array}{l}\mathrm{J} 2- \\
311- \\
\text { MS- } \\
\text { BR } \\
\end{array}$ & $\begin{array}{l}\text { M3 } \\
9\end{array}$ & $\begin{array}{l}20 \\
07\end{array}$ & $\begin{array}{l}47 . \\
4\end{array}$ & $\begin{array}{l}6 . \\
2 \\
1\end{array}$ & $\begin{array}{l}13 . \\
7\end{array}$ & $\begin{array}{l}1 \\
7 . \\
2\end{array}$ & $\begin{array}{l}553 \\
.7\end{array}$ & \begin{tabular}{|l|}
23 \\
.4
\end{tabular} & $\begin{array}{l}35 \\
91\end{array}$ & $\begin{array}{l}10 \\
2 . \\
4\end{array}$ & $\begin{array}{l}23 . \\
7\end{array}$ & 28.5 & 1.21 & $\begin{array}{l}0 . \\
1 \\
1\end{array}$ \\
\hline $\begin{array}{l}\text { J2- } \\
315- \\
\text { MS- } \\
\text { BL }\end{array}$ & $\begin{array}{l}\text { M3 } \\
9\end{array}$ & $\begin{array}{l}20 \\
07\end{array}$ & $\begin{array}{l}52 . \\
0\end{array}$ & $\begin{array}{l}6 . \\
0 \\
8\end{array}$ & $\begin{array}{l}15 . \\
6\end{array}$ & $\begin{array}{l}1 \\
8 . \\
1\end{array}$ & $\begin{array}{l}556 \\
.4\end{array}$ & \begin{tabular}{|l|}
23 \\
.7
\end{tabular} & $\begin{array}{l}40 \\
10\end{array}$ & $\begin{array}{l}11 \\
8 . \\
0\end{array}$ & $\begin{array}{l}23 . \\
5\end{array}$ & 29.4 & 1.91 & $\begin{array}{l}0 . \\
1 \\
1\end{array}$ \\
\hline $\begin{array}{l}\text { J2- } \\
242- \\
\text { MS3 }\end{array}$ & $\begin{array}{l}\mathrm{M3} \\
9\end{array}$ & $\begin{array}{l}20 \\
06\end{array}$ & $\begin{array}{l}51 . \\
0\end{array}$ & $\begin{array}{l}5 . \\
8 \\
8\end{array}$ & $\begin{array}{l}15 . \\
0\end{array}$ & $\begin{array}{l}1 \\
8 . \\
6\end{array}$ & $\begin{array}{l}568 \\
.8\end{array}$ & $\begin{array}{l}22 \\
.2\end{array}$ & $\begin{array}{l}38 \\
30\end{array}$ & $\begin{array}{l}11 \\
8 . \\
9\end{array}$ & $\begin{array}{l}25 . \\
6\end{array}$ & 31.0 & 1.54 & $\begin{array}{l}0 . \\
1 \\
1\end{array}$ \\
\hline $\begin{array}{l}\mathrm{J} 2- \\
242- \\
\text { MS4 }\end{array}$ & $\begin{array}{l}\text { M3 } \\
9\end{array}$ & $\begin{array}{l}20 \\
06\end{array}$ & $\begin{array}{l}51 . \\
0\end{array}$ & $\begin{array}{l}5 . \\
9 \\
4\end{array}$ & $\begin{array}{l}15 . \\
0\end{array}$ & $\begin{array}{l}1 \\
8 . \\
2\end{array}$ & $\begin{array}{l}558 \\
.6\end{array}$ & $\begin{array}{l}22 \\
.1\end{array}$ & $\begin{array}{l}36 \\
79\end{array}$ & $\begin{array}{l}12 \\
9 . \\
8\end{array}$ & $\begin{array}{l}25 . \\
3\end{array}$ & 35.3 & 1.19 & $\begin{array}{l}0 . \\
1 \\
1\end{array}$ \\
\hline $\begin{array}{l}\mathrm{J} 2- \\
245- \\
\text { MS2 }\end{array}$ & $\begin{array}{l}\mathrm{M} 3 \\
9\end{array}$ & $\begin{array}{l}20 \\
06\end{array}$ & $\begin{array}{l}50 . \\
0\end{array}$ & $\begin{array}{l}5 . \\
7 \\
7\end{array}$ & $\begin{array}{l}15 . \\
0\end{array}$ & $\begin{array}{l}1 \\
8 . \\
2\end{array}$ & $\begin{array}{l}584 \\
.1\end{array}$ & $\begin{array}{l}23 \\
.0\end{array}$ & $\begin{array}{l}37 \\
57\end{array}$ & $\begin{array}{l}11 \\
5 . \\
0\end{array}$ & $\begin{array}{l}25 . \\
4\end{array}$ & 30.6 & 1.21 & $\begin{array}{l}0 . \\
1 \\
1\end{array}$ \\
\hline Pele's & & & & & & & & & & & 27. & 31.4 & 1.68 & $\underline{0}$. \\
\hline
\end{tabular}




\begin{tabular}{|c|c|c|c|c|c|c|c|c|c|c|c|c|c|c|}
\hline $\begin{array}{l}\text { pit } \\
\text { vents } \\
= \\
\underline{\text { avera }} \\
\underline{\text { ge }}\end{array}$ & & & & & & & & & & & $\underline{21}$ & $\underline{8}$ & & $\underline{\underline{7}}$ \\
\hline $\begin{array}{l}\text { Lohia } \\
\underline{u} \\
\text { Area } \\
\text { (M5) }\end{array}$ & & & & & & & & & & & & & & \\
\hline $\begin{array}{l}\overline{J 2-} \\
311- \\
\text { MS- } \\
\text { RL }\end{array}$ & M5 & $\begin{array}{l}20 \\
07\end{array}$ & $\begin{array}{l}24 . \\
5\end{array}$ & $\begin{array}{l}6 . \\
9 \\
4\end{array}$ & 5.6 & $\begin{array}{l}1 \\
2 . \\
9\end{array}$ & $\begin{array}{l}68 . \\
3\end{array}$ & $\begin{array}{l}10 \\
.0\end{array}$ & $\begin{array}{l}67 \\
5\end{array}$ & $\begin{array}{l}34 \\
.9\end{array}$ & 6.8 & 51.8 & 1.15 & $\begin{array}{l}0 . \\
1 \\
1\end{array}$ \\
\hline $\begin{array}{l}\text { J2- } \\
311- \\
\text { MS- } \\
\text { RR }\end{array}$ & M5 & $\begin{array}{l}20 \\
07\end{array}$ & $\begin{array}{l}24 . \\
5\end{array}$ & $\begin{array}{l}6 . \\
6 \\
5\end{array}$ & 6.6 & $\begin{array}{l}1 \\
2 . \\
6\end{array}$ & $\begin{array}{l}58 . \\
0\end{array}$ & $\begin{array}{l}8 . \\
0\end{array}$ & $\begin{array}{l}62 \\
8\end{array}$ & $\begin{array}{l}15 \\
.0 \\
\end{array}$ & 7.2 & 23.9 & 1.23 & $\begin{array}{l}0 . \\
1 \\
1\end{array}$ \\
\hline $\begin{array}{l}\mathrm{J} 2- \\
242- \\
\text { MS1 }\end{array}$ & M5 & $\begin{array}{l}20 \\
06\end{array}$ & $\begin{array}{l}21 . \\
0\end{array}$ & $\begin{array}{l}6 . \\
2 \\
1\end{array}$ & 3.4 & $\begin{array}{l}1 \\
1 . \\
5\end{array}$ & $\begin{array}{l}57 . \\
7\end{array}$ & $\begin{array}{l}2 . \\
8\end{array}$ & $\begin{array}{l}36 \\
9\end{array}$ & $\begin{array}{l}14 \\
.2 \\
\end{array}$ & $\begin{array}{l}20 . \\
4\end{array}$ & 38.5 & 0.95 & $\begin{array}{l}0 . \\
1 \\
1 \\
\end{array}$ \\
\hline $\begin{array}{l}\text { J2- } \\
245- \\
\text { MS1 }\end{array}$ & M5 & $\begin{array}{l}20 \\
06\end{array}$ & $\begin{array}{l}22 . \\
0\end{array}$ & $\begin{array}{l}5 . \\
8 \\
9\end{array}$ & 9.3 & $\begin{array}{l}1 \\
6 . \\
5\end{array}$ & $\begin{array}{l}234 \\
.7\end{array}$ & $\begin{array}{l}21 \\
.8\end{array}$ & $\begin{array}{l}15 \\
58\end{array}$ & $\begin{array}{l}32 \\
.7\end{array}$ & $\begin{array}{l}10 . \\
8\end{array}$ & 21.0 & 1.20 & $\begin{array}{l}0 . \\
1 \\
1 \\
\end{array}$ \\
\hline $\begin{array}{l}\text { Lohia } \\
\underline{u} \\
\text { area - } \\
\text { avera } \\
\underline{\text { ge }}\end{array}$ & & & & & & & & & & & $\frac{11 .}{\underline{30}}$ & $\frac{33.8}{\underline{0}}$ & 1.13 & \begin{tabular}{|l}
$\frac{0 .}{2}$ \\
$\frac{5}{5}$
\end{tabular} \\
\hline$\frac{\text { Pohak }}{\text { u area }}$ & & & & & & & & & & & & & & \\
\hline $\begin{array}{l}\text { J2- } \\
368- \\
\text { MS- } \\
\text { black }\end{array}$ & $\begin{array}{l}\text { M5 } \\
7\end{array}$ & $\begin{array}{l}20 \\
08\end{array}$ & $\begin{array}{l}28 . \\
3\end{array}$ & $\begin{array}{l}6 . \\
5 \\
2\end{array}$ & & $\begin{array}{l}1 \\
0 . \\
7\end{array}$ & $\begin{array}{l}507 \\
.2\end{array}$ & $\begin{array}{l}12 \\
.4\end{array}$ & $\begin{array}{l}15 \\
53\end{array}$ & $\begin{array}{l}10 \\
.1\end{array}$ & $\begin{array}{l}40 . \\
9\end{array}$ & 6.5 & 0.61 & $\begin{array}{l}0 . \\
1 \\
1\end{array}$ \\
\hline $\begin{array}{l}\text { J2- } \\
368- \\
\text { MS- } \\
\text { red }\end{array}$ & $\begin{array}{l}\text { M5 } \\
7\end{array}$ & $\begin{array}{l}20 \\
08\end{array}$ & $\begin{array}{l}26 . \\
7\end{array}$ & $\begin{array}{l}5 . \\
5 \\
9\end{array}$ & & $\begin{array}{l}1 \\
1 . \\
4\end{array}$ & $\begin{array}{l}773 \\
.4\end{array}$ & $\begin{array}{l}19 \\
.0\end{array}$ & $\begin{array}{l}22 \\
75\end{array}$ & $\begin{array}{l}21 \\
.2\end{array}$ & $\begin{array}{l}40 . \\
7\end{array}$ & 9.3 & 0.74 & $\begin{array}{l}0 . \\
1 \\
1\end{array}$ \\
\hline $\begin{array}{l}\frac{\text { Poha }}{\text { ku }} \\
\frac{\text { area - }}{\text { avera }} \\
\text { ge } \\
\text { Eor }\end{array}$ & & & & & & & & & & & $\frac{40 .}{81}$ & $\underline{7.92}$ & $\underline{0.67}$ & $\begin{array}{l}\frac{0 .}{1} \\
\underline{8}\end{array}$ \\
\hline East $P$ & ifific & Zise & $9^{\circ} 50$ & & & & & & & & & & & \\
\hline $\begin{array}{l}\text { ALV- } \\
4057- \\
\text { W1 } \\
\end{array}$ & $\begin{array}{l}\text { Bio } \\
9^{\prime \prime}\end{array}$ & $\begin{array}{l}20 \\
04\end{array}$ & $\begin{array}{l}38 \\
3.0\end{array}$ & $\begin{array}{l}3 . \\
2 \\
1\end{array}$ & & $\begin{array}{l}1 \\
1 . \\
9\end{array}$ & $\begin{array}{l}317 \\
3.0\end{array}$ & $\begin{array}{l}48 \\
3 . \\
0\end{array}$ & $\begin{array}{l}11 \\
08 \\
0\end{array}$ & $\begin{array}{l}10 \\
3 . \\
3\end{array}$ & 6.6 & 8.1 & 1.46 & $\begin{array}{l}0 . \\
1 \\
1 \\
\end{array}$ \\
\hline $\begin{array}{l}\text { ALV- } \\
4057-\end{array}$ & $\begin{array}{l}\text { Bio } \\
9^{\prime \prime}\end{array}$ & $\begin{array}{l}20 \\
04 \\
\end{array}$ & $\begin{array}{l}38 \\
3.0 \\
\end{array}$ & $\begin{array}{l}3 . \\
3 \\
\end{array}$ & & $\begin{array}{l}1 \\
1 . \\
\end{array}$ & $\begin{array}{l}308 \\
8.0 \\
\end{array}$ & $\begin{array}{l}46 \\
1 . \\
\end{array}$ & $\begin{array}{l}11 \\
08 \\
\end{array}$ & $\begin{array}{l}75 \\
.5 \\
\end{array}$ & 6.7 & 8.1 & 1.68 & $\begin{array}{l}0 . \\
1\end{array}$ \\
\hline
\end{tabular}




\begin{tabular}{|c|c|c|c|c|c|c|c|c|c|c|c|c|c|c|}
\hline W2 & & & & 0 & & 9 & & 0 & 0 & & & & & 1 \\
\hline $\begin{array}{l}\text { ALV- } \\
4059- \\
\text { W1 }\end{array}$ & $\begin{array}{l}\text { Tic } \\
a \\
\text { Ven } \\
t\end{array}$ & $\begin{array}{l}20 \\
04\end{array}$ & $\begin{array}{l}34 \\
4.0\end{array}$ & $\begin{array}{l}3 . \\
1 \\
6\end{array}$ & & $\begin{array}{l}1 \\
1 . \\
5\end{array}$ & $\begin{array}{l}141 \\
7.0\end{array}$ & $\begin{array}{l}37 \\
7 . \\
0\end{array}$ & $\begin{array}{l}13 \\
10 \\
5\end{array}$ & $\begin{array}{l}51 \\
.1\end{array}$ & 3.8 & 3.7 & 1.23 & $\begin{array}{l}0 . \\
1 \\
1\end{array}$ \\
\hline $\begin{array}{l}\text { ALV- } \\
4059- \\
\text { W2 }\end{array}$ & $\begin{array}{l}\text { Tic } \\
a \\
\text { Ven } \\
t\end{array}$ & $\begin{array}{l}20 \\
04\end{array}$ & $\begin{array}{l}34 \\
4.0\end{array}$ & $\begin{array}{l}3 . \\
1 \\
3\end{array}$ & & $\begin{array}{l}1 \\
1 . \\
1\end{array}$ & $\begin{array}{l}138 \\
1.0\end{array}$ & $\begin{array}{l}36 \\
9 . \\
0\end{array}$ & $\begin{array}{l}13 \\
10 \\
5\end{array}$ & $\begin{array}{l}46 \\
.4\end{array}$ & 3.7 & 3.7 & 1.54 & $\begin{array}{l}0 . \\
1 \\
1\end{array}$ \\
\hline $\begin{array}{l}\text { ALV- } \\
4061- \\
\text { W3 }\end{array}$ & $\begin{array}{l}\text { Bio } \\
\text { ven } \\
t\end{array}$ & $\begin{array}{l}20 \\
04\end{array}$ & $\begin{array}{l}33 \\
1.0\end{array}$ & $\begin{array}{l}4 . \\
4 \\
5\end{array}$ & & $\begin{array}{l}1 \\
0 . \\
1\end{array}$ & $\begin{array}{l}156 \\
.0\end{array}$ & $\begin{array}{l}10 \\
1 . \\
0\end{array}$ & $\begin{array}{l}14 \\
85 \\
5\end{array}$ & $\begin{array}{l}79 \\
.4\end{array}$ & 1.5 & 6.8 & 1.71 & $\begin{array}{l}0 . \\
1 \\
1\end{array}$ \\
\hline $\begin{array}{l}\text { ALV- } \\
4061- \\
\text { W4 }\end{array}$ & $\begin{array}{l}\text { Bio } \\
\text { ven } \\
t\end{array}$ & $\begin{array}{l}20 \\
04\end{array}$ & $\begin{array}{l}33 \\
1.0\end{array}$ & $\begin{array}{l}3 . \\
7 \\
9\end{array}$ & & $\begin{array}{l}9 . \\
5\end{array}$ & $\begin{array}{l}265 \\
.0\end{array}$ & $\begin{array}{l}18 \\
0 . \\
0\end{array}$ & $\begin{array}{l}14 \\
85 \\
5\end{array}$ & $\begin{array}{l}11 \\
5 . \\
1\end{array}$ & 0 & 6.8 & 1.65 & $\begin{array}{l}0 . \\
1 \\
1\end{array}$ \\
\hline 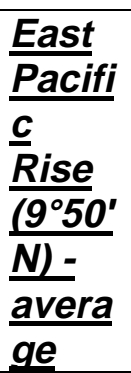 & & & & & & & & & & & $\frac{3.9}{\underline{6}}$ & $\underline{6.20}$ & 1.55 & $\underline{\underline{0}} \underline{\underline{36}}$ \\
\hline $\begin{array}{l}\text { Avera } \\
\text { ge } \\
\text { igneo } \\
\text { us } \\
\text { crust } \\
\text { (d) }\end{array}$ & & & & & & & & & & & $\begin{array}{l}2.4 \\
0\end{array}$ & 0.56 & 0.08 & \\
\hline $\begin{array}{l}\text { Backg } \\
\text { round } \\
\text { seawa } \\
\text { ter }(e)\end{array}$ & & $\begin{array}{l}2 . \\
0\end{array}$ & $\begin{array}{l}8.3 \\
0\end{array}$ & & $\begin{array}{l}10 . \\
3\end{array}$ & $\begin{array}{l}< \\
0 . \\
0 \\
1\end{array}$ & $\begin{array}{l}< \\
0.0 \\
05\end{array}$ & 75 & $\begin{array}{l}0.1 \\
0\end{array}$ & & $\begin{array}{l}0.7 \\
2\end{array}$ & 3.00 & 0.60 & \\
\hline
\end{tabular}

(a) Chemical data for Loihi Seamount and EPR $9^{\circ} 50^{\prime} \mathrm{N}$ are from Glazer et al. (2009) and Rouxel et al. (2008) respectively. Alk: total alkalinity in meq/kg determined by titration.

(b) Si concentration at EPR $9-10^{\circ} \mathrm{N}$ determined by ICP-AES (Si data for Loihi are from Glazer and Rouxel, 2009)

(c) Ge concentration determined by isotope dillution and HG-MC-ICPMS analysis, this study

(d) Estimation of average $8^{4 / 70} \mathrm{Ge}$ of the igneous crust is from Rouxel et al. (2006) and normalized relative to NIST3120a standard in Escoube et al. (2012)

(e) Estimation of seawater $8^{4 / 70} \mathrm{Ge}$ value based on the analysis of marine biogenic opal (Rouxel et al., 2006, Mantoura et al., 2006) after renormalization to NIST3120a (Escoube et al., 2012) and preliminary seawater analysis reported by Baronas et al. 
(2014). Other data data were obtained on background seawater sample recovered above Loihi Seamount

Table 2: Geochemical and $\mathrm{Ge}$ isotopic composition of Fe-rich deposits at Loihi

Seamount

\begin{tabular}{|c|c|c|c|c|c|c|c|c|c|c|}
\hline $\begin{array}{l}\text { Sample } \\
\text { Name }\end{array}$ & Marker & Year & $\begin{array}{l}\mathrm{Si} \\
\text { (wt\% } \\
)^{2}\end{array}$ & $\begin{array}{l}\mathrm{Al} \\
\text { (wt\% } \\
)^{2}\end{array}$ & $\begin{array}{l}\mathrm{Fe} \\
\text { (wt\% } \\
)^{2}\end{array}$ & $\begin{array}{l}P \\
(\mathrm{~g} / \mathrm{g})\end{array}$ & $\begin{array}{l}\mathrm{Ge} \\
(\mathrm{lg} / \mathrm{g} \\
)^{2}\end{array}$ & $\begin{array}{l}\mathrm{Ge} / \mathrm{Si} \\
(\mu \mathrm{mol} / \mathrm{m} \\
\mathrm{ol})\end{array}$ & $\begin{array}{l}\delta^{4 / 70} \mathrm{Ge} \\
\text { NIST312 } \\
\text { 0a }\end{array}$ & $2 s d$ \\
\hline \multicolumn{11}{|c|}{ Pele's Pit, Hiolo area } \\
\hline $\begin{array}{l}\text { J2-245- } \\
\text { SS1 }\end{array}$ & M36 & $\begin{array}{l}200 \\
6\end{array}$ & 9.58 & 2.31 & $\begin{array}{l}29.1 \\
1\end{array}$ & 9518 & 9.2 & 37.5 & -0.08 & $\begin{array}{l}0.2 \\
0\end{array}$ \\
\hline $\begin{array}{l}\text { duplicat } \\
e\end{array}$ & & & & & & & & & -0.10 & $\begin{array}{l}0.2 \\
0\end{array}$ \\
\hline $\begin{array}{l}\mathrm{J} 2-245- \\
\mathrm{SS} 4\end{array}$ & M36 & $\begin{array}{l}200 \\
6\end{array}$ & 7.70 & 1.84 & $\begin{array}{l}27.2 \\
1 \\
\end{array}$ & $\begin{array}{l}1384 \\
1 \\
\end{array}$ & 8.6 & 43.3 & -0.06 & $\begin{array}{l}0.2 \\
0\end{array}$ \\
\hline $\begin{array}{l}\text { J2-242- } \\
\text { SS4 }\end{array}$ & M39 & $\begin{array}{l}200 \\
6\end{array}$ & 5.19 & 0.13 & $\begin{array}{l}38.3 \\
7 \\
\end{array}$ & 8645 & $\begin{array}{l}16 . \\
5\end{array}$ & 123.4 & -0.23 & $\begin{array}{l}0.2 \\
0\end{array}$ \\
\hline $\begin{array}{l}\text { duplicat } \\
e\end{array}$ & & & & & & & & & -0.34 & $\begin{array}{l}0.1 \\
3\end{array}$ \\
\hline $\begin{array}{l}\text { J2-308- } \\
\text { SS1 }\end{array}$ & M39 & $\begin{array}{l}200 \\
7\end{array}$ & 9.03 & 1.24 & $\begin{array}{l}26.8 \\
9\end{array}$ & 7466 & $\begin{array}{l}18 . \\
0\end{array}$ & 77.6 & -0.61 & $\begin{array}{l}0.1 \\
3\end{array}$ \\
\hline \multicolumn{11}{|c|}{ Pele's Pit, Spillway area } \\
\hline $\begin{array}{l}\text { J2-245- } \\
\text { SS5 }\end{array}$ & M34 & $\begin{array}{l}200 \\
6 \\
\end{array}$ & 9.38 & 0.33 & $\begin{array}{l}33.2 \\
3 \\
\end{array}$ & 8820 & $\begin{array}{l}23 . \\
5\end{array}$ & 97.5 & -0.28 & $\begin{array}{l}0.2 \\
0\end{array}$ \\
\hline $\begin{array}{l}\text { duplicat } \\
e\end{array}$ & & & & & & & & & -0.26 & $\begin{array}{l}0.1 \\
3\end{array}$ \\
\hline $\begin{array}{l}\text { J2-308- } \\
\text { SS2 }\end{array}$ & M34 & $\begin{array}{l}200 \\
7\end{array}$ & $\begin{array}{l}15.5 \\
1\end{array}$ & 0.69 & $\begin{array}{l}24.3 \\
6\end{array}$ & 6549 & $\begin{array}{l}23 . \\
1\end{array}$ & 58.0 & -0.66 & $\begin{array}{l}0.1 \\
3\end{array}$ \\
\hline $\begin{array}{l}\text { J2-314- } \\
\text { SSA/B }\end{array}$ & $\begin{array}{l}\text { M34/3 } \\
8\end{array}$ & $\begin{array}{l}200 \\
7\end{array}$ & 6.73 & 0.76 & $\begin{array}{l}31.9 \\
0 \\
\end{array}$ & $\begin{array}{l}1017 \\
3 \\
\end{array}$ & $\begin{array}{l}20 . \\
5\end{array}$ & 118.1 & 0.16 & $\begin{array}{l}0.1 \\
3 \\
\end{array}$ \\
\hline \multicolumn{11}{|l|}{$\begin{array}{l}\text { Lohiau } \\
\text { area }\end{array}$} \\
\hline $\begin{array}{l}\mathrm{J} 2-311- \\
\mathrm{SS} 1\end{array}$ & M2 & $\begin{array}{l}200 \\
7\end{array}$ & $\begin{array}{l}10.0 \\
7\end{array}$ & 1.65 & $\begin{array}{l}28.1 \\
9\end{array}$ & 6244 & $\begin{array}{l}26 . \\
5\end{array}$ & 102.3 & -0.98 & $\begin{array}{l}0.1 \\
3\end{array}$ \\
\hline $\begin{array}{l}\mathrm{J} 2-245- \\
\mathrm{SS} 3\end{array}$ & M5 & $\begin{array}{l}200 \\
6\end{array}$ & 7.28 & 0.41 & $\begin{array}{l}34.7 \\
0\end{array}$ & 6375 & $\begin{array}{l}27 . \\
6\end{array}$ & 147.6 & -0.75 & $\begin{array}{l}0.2 \\
0\end{array}$ \\
\hline duplicat & & & & & & & & & -0.67 & $\begin{array}{l}0.1 \\
3\end{array}$ \\
\hline $\begin{array}{l}\mathrm{J} 2-242- \\
\mathrm{SS} 2\end{array}$ & M5 & $\begin{array}{l}200 \\
6\end{array}$ & 6.06 & 0.04 & $\begin{array}{l}40.3 \\
7 \\
\end{array}$ & 5196 & $\begin{array}{l}29 . \\
5\end{array}$ & 189.4 & -0.41 & $\begin{array}{l}0.1 \\
3\end{array}$ \\
\hline $\begin{array}{l}\text { J2-310- } \\
\text { SS2 }\end{array}$ & M5 & $\begin{array}{l}200 \\
7 \\
\end{array}$ & 7.42 & 0.33 & $\begin{array}{l}34.5 \\
7 \\
\end{array}$ & 6287 & $\begin{array}{l}28 . \\
8\end{array}$ & 150.7 & -0.69 & $\begin{array}{l}0.1 \\
3\end{array}$ \\
\hline \multicolumn{11}{|l|}{$\begin{array}{l}\text { Pohaku } \\
\text { area }\end{array}$} \\
\hline $\begin{array}{l}\mathrm{J} 2-316- \\
\mathrm{SS} 1\end{array}$ & M57 & $\begin{array}{l}200 \\
7\end{array}$ & 2.50 & 0.06 & $\begin{array}{l}41.1 \\
0\end{array}$ & $\begin{array}{l}1113 \\
4\end{array}$ & 4.8 & 74.4 & -0.21 & $\begin{array}{l}0.1 \\
3\end{array}$ \\
\hline $\begin{array}{l}\text { Averag } \\
e\end{array}$ & & & & & 1.00 & 2.20 & $\begin{array}{l}0.5 \\
6 \\
\end{array}$ & 0.08 & & \\
\hline
\end{tabular}




\begin{tabular}{|l|l|l|l|l|l|l|l|l|l|l|}
\hline $\begin{array}{l}\text { igneous } \\
\text { crust } \\
\text { (a) }\end{array}$ & & & & & & & & & \\
\hline
\end{tabular}

(a) Estimation of the igneous crust is from Rouxel et al. (2006) and normalized relative to NIST3120a standard as described in Escoube et al. (2012)

Table 3: Chemical composition and sample description of mineral separates of active and inactive sulfide deposits from East Pacific Rise (EPR) at 9 $50^{\prime} \mathrm{N}$

\begin{tabular}{|c|c|c|c|c|c|c|c|c|c|}
\hline $\begin{array}{l}\text { Sampl } \\
\text { e } \\
\text { Name }\end{array}$ & $\begin{array}{l}\text { mineral } \\
\mathrm{s}(\mathrm{a})\end{array}$ & $\begin{array}{l}\text { Fe } \\
\text { (wt\% } \\
\text { ) }\end{array}$ & $\begin{array}{l}\mathrm{Cu} \\
\text { (wt\% } \\
\text { ) }\end{array}$ & $\begin{array}{l}\mathrm{Zn} \\
(w t \% \\
\text { ) }\end{array}$ & $\begin{array}{l}\mathrm{Ca} \\
(\mathrm{wt} \% \\
\text { ) }\end{array}$ & $\begin{array}{l}\mathrm{Pb} \\
(\mathrm{wt} \% \\
\text { ) }\end{array}$ & $\begin{array}{l}\mathrm{Ge} \\
(\mathrm{hg} / \mathrm{g})\end{array}$ & $\begin{array}{l}8^{4 / 70} \mathrm{Ge} \\
\text { NIST3120 } \\
a\end{array}$ & 2sd \\
\hline \multicolumn{10}{|c|}{ Bio 9" (Cu-rich chimneys) } \\
\hline $\begin{array}{l}\text { ALV- } \\
4057- \\
\text { M1 } \\
\# A 1\end{array}$ & sph-py & 26.35 & 0.59 & 22.67 & 0.02 & 0.07 & 8.22 & -3.71 & $\begin{array}{l}0.1 \\
8\end{array}$ \\
\hline $\begin{array}{l}\text { ALV- } \\
4057- \\
\text { M1 } \\
\text { \#A3 }\end{array}$ & sph-py & 26.33 & 1.88 & 23.98 & 0.09 & 0.06 & 4.73 & -3.82 & $\begin{array}{l}0.1 \\
8\end{array}$ \\
\hline $\begin{array}{l}\text { ALV- } \\
4057- \\
\text { M1 } \\
\text { \#A4 }\end{array}$ & sph-py & 21.13 & 2.32 & 26.51 & 0.03 & 0.06 & $\begin{array}{l}11.0 \\
0\end{array}$ & -4.08 & $\begin{array}{l}0.1 \\
8\end{array}$ \\
\hline $\begin{array}{l}\text { ALV- } \\
4057- \\
\text { M1 } \\
\text { \#A5 }\end{array}$ & sph-py & 25.51 & & 22.90 & 0.03 & 0.06 & 7.14 & -4.37 & $\begin{array}{l}0.1 \\
8\end{array}$ \\
\hline \multicolumn{10}{|c|}{ Fe-Zn-rich inactive chimneys } \\
\hline $\begin{array}{l}\text { ALV- } \\
4053- \\
\text { M3 } \\
\end{array}$ & sph-py & 16.03 & 0.40 & 28.44 & 0.01 & 0.73 & $\begin{array}{l}27.3 \\
7\end{array}$ & -3.60 & $\begin{array}{l}0.1 \\
8\end{array}$ \\
\hline $\begin{array}{l}\text { ALV- } \\
4057- \\
\text { M2 }\end{array}$ & $\begin{array}{l}\text { sph-py- } \\
\text { mar }\end{array}$ & 16.20 & 0.32 & 37.76 & 0.11 & 0.03 & $\begin{array}{l}13.1 \\
9\end{array}$ & -4.02 & $\begin{array}{l}0.1 \\
8\end{array}$ \\
\hline $\begin{array}{l}\text { ALV- } \\
4059- \\
\text { M3 }\end{array}$ & sph & 9.79 & 0.38 & 45.38 & 0.03 & 0.02 & $\begin{array}{l}10.3 \\
4\end{array}$ & -4.71 & $\begin{array}{l}0.1 \\
8\end{array}$ \\
\hline
\end{tabular}

$\mathrm{Fe}, \mathrm{Cu} \mathrm{Zn}, \mathrm{Ca}$ and $\mathrm{Pb}$ determined by ICP-AES (detection limit $0.01 \%$ ); Ge concentration and isotope ration determined by HG-ICPMS following the method described in Rouxel et al. (2006)

(a) mar: marcasite; py: pyrite; sph: sphalerite. Additional description of the samples is available in Rouxel et al. (2008) 
Table 4: Summary of $\mathrm{Ge} / \mathrm{Si}$ and $\delta^{74 / 70} \mathrm{Ge}$ ratios measured in seafloor hydrothermal fluids

\begin{tabular}{|c|c|c|c|c|c|c|c|c|}
\hline Site $\left({ }^{*}\right)$ & Sample type & $\begin{array}{l}\text { Temp } \\
\left({ }^{\circ} \mathrm{C}\right)\end{array}$ & $\begin{array}{c}\mathrm{Si} \\
(\mu \mathrm{M})\end{array}$ & $\begin{array}{c}\mathrm{Ge} / \mathrm{Si} \\
(\mu \mathrm{mol} / \mathrm{mol})\end{array}$ & $2 s d$ & $\begin{array}{c}8^{8 / 70} \mathrm{Ge} \\
(\% \circ)\end{array}$ & $2 s d$ & $\begin{array}{l}\text { data } \\
\text { source }\end{array}$ \\
\hline & \multicolumn{3}{|c|}{ Average igneous rock } & 2.4 & & 0.56 & 0.09 & (a) \\
\hline & $\begin{array}{l}\text { Seawater } \\
\text { estimate }\end{array}$ & 2 & 180 & 0.7 & & 3.00 & 0.60 & (b) \\
\hline Loihi & Pele's Pit area & 47 & 4664 & 31.5 & 7.3 & 1.68 & 0.70 & (c) \\
\hline Loihi & Lohiau area & 23 & 1558 & 33.8 & 28.5 & 1.13 & 0.25 & (c) \\
\hline Loihi & Pohaku area & 27 & 2275 & 7.9 & 4.0 & 0.67 & 0.18 & (c) \\
\hline EPR & $9^{\circ} 50^{\prime} \mathrm{N}$ area & 353 & 20000 & 6.2 & 4.0 & 1.55 & 0.36 & (c) \\
\hline EPR & $21^{\circ} \mathrm{N}$ area & $\mathrm{HT}$ & 16519 & 8.7 & 3.4 & & & (d) \\
\hline JdFR & North Cleft area & HT & 22000 & 9.5 & 7.0 & & & (d) \\
\hline $\begin{array}{c}\text { Axial } \\
\text { Volcano }\end{array}$ & Axial Volcano & HT & 12500 & 10.8 & 1.7 & & & (d) \\
\hline $\begin{array}{l}\text { Axial } \\
\text { Volcano }\end{array}$ & Inferno area & HT & 71175 & 136 & 3.1 & & & (d) \\
\hline JdFR & Cleft segment & $\mathrm{HT}$ & 22250 & 10.7 & 5.3 & & & (d) \\
\hline JdFR & Baby Bare & 63 & 360 & 34.0 & & & & (e) \\
\hline JdFR & ODP Hole 1025 & 40.5 & 580 & 15.0 & & & & (e) \\
\hline JdFR & ODP Hole 1026 & 63 & 710 & 27.0 & & & & (e) \\
\hline JdFR & ODP Hole 1027 & 63 & 320 & 62.0 & & & & (e) \\
\hline JdFR & ODP Hole 1024 & 23 & 50 & 17.0 & & & & (e) \\
\hline EPR & Dorado outcrop & 7 & 180 & 1.7 & & & & (e) \\
\hline EPR & $14^{\circ} \mathrm{S}$ & 3 & 170 & 0.7 & & & & (e) \\
\hline
\end{tabular}

(*) EPR: East Pacific Rise; JdFR: Juan de Fuca Ridge

(a) Estimation of average $\delta^{4 / 70} \mathrm{Ge}$ of the igneous crust is from Rouxel et al. (2006) and normalized relative to NIST3120a standard (Escoube et al., 2012)

(b) Estimation of $8^{4 / 70} \mathrm{Ge}$ seawater value based on the analysis of marine biogenic opal (Rouxel et al., 2006, Mantoura et al., 2006) after renormalization to NIST3120a standard

(c) This study; average values calculated from data reported in Table 1

(d) Average values of high-temperature (HT) hydrothermal vents from Mortlock et Froelich (1993)

(e) Individual data of warm and cold basaltic formation fluids from ridge flank hydrothermal systems, from Wheat and McManus (2008) 
Table 5: Determination of Ge distribution among the different phases of Fe-rich deposits at Loihi and estimation of the $\mathrm{Ge}$ isotope fractionation factor between $\mathrm{FeOOH}$ and hydrothermal fluid.

\begin{tabular}{|c|c|c|c|c|c|c|c|c|c|c|c|c|c|c|}
\hline $\begin{array}{l}\text { Sam } \\
\text { ple } \\
\text { Nam } \\
\text { e }\end{array}$ & $\begin{array}{l}\text { Mar } \\
\text { ker }\end{array}$ & $\begin{array}{l}X G \\
\mathrm{e} \\
\mathrm{Ba} \\
\mathrm{s} \\
\text { (a) }\end{array}$ & $2 s d$ & $\begin{array}{l}X \\
G \\
e \\
A \\
m \\
0 \\
\text { (a) }\end{array}$ & $\begin{array}{l}2 s \\
d\end{array}$ & $\begin{array}{l}\text { XGe } \\
\mathrm{FeO} \\
\mathrm{OH} \\
\text { (a) }\end{array}$ & $\begin{array}{l}2 s \\
d\end{array}$ & $\begin{array}{l}8^{4 / 70} \\
\text { Ge } \\
\text { bulk } \\
\text { (b) }\end{array}$ & $\begin{array}{l}2 s \\
d\end{array}$ & $\begin{array}{l}8^{4 / 70} \\
\mathrm{Ge} \\
\mathrm{FeO} \\
\mathrm{OH}\end{array}$ & $\begin{array}{l}2 s \\
d\end{array}$ & $\begin{array}{l}\Delta^{4 / 70} \\
\mathrm{Ge} \\
\mathrm{FeO} \\
\mathrm{OH}- \\
\text { Fluid } \\
\text { (c) }\end{array}$ & $\begin{array}{l}2 s \\
d\end{array}$ & $\begin{array}{l}f \\
\mathrm{ad} \\
\mathrm{s}\end{array}$ \\
\hline \multicolumn{15}{|c|}{ Pele's Pit, Hiolo area } \\
\hline $\begin{array}{l}\mathrm{J} 2- \\
245- \\
\text { SS1 }\end{array}$ & M36 & $\begin{array}{l}0.0 \\
4\end{array}$ & $\begin{array}{l}<0 . \\
01\end{array}$ & $\begin{array}{l}0 . \\
11\end{array}$ & $\begin{array}{l}0 . \\
10\end{array}$ & 0.85 & $\begin{array}{l}0 . \\
10\end{array}$ & $\overline{0} 0.08$ & $\begin{array}{l}0 . \\
20\end{array}$ & \multicolumn{2}{|c|}{\begin{tabular}{|l|l|}
- & 0. \\
0.33 & 37
\end{tabular}} & -1.89 & $\begin{array}{l}0 . \\
77\end{array}$ & $\begin{array}{l}0 . \\
37\end{array}$ \\
\hline $\begin{array}{l}\mathrm{J} 2- \\
245- \\
\text { SS4 }\end{array}$ & M36 & $\begin{array}{l}0.0 \\
3\end{array}$ & $\begin{array}{l}<0 . \\
01\end{array}$ & $\begin{array}{l}0 . \\
10\end{array}$ & $\begin{array}{l}0 . \\
09\end{array}$ & 0.87 & $\begin{array}{l}0 . \\
09\end{array}$ & 0.06 & $\begin{array}{l}0 . \\
20\end{array}$ & 0.26 & $\begin{array}{l}0 . \\
22\end{array}$ & -1.65 & $\begin{array}{l}0 . \\
69\end{array}$ & $\begin{array}{l}0 . \\
45\end{array}$ \\
\hline $\begin{array}{l}\mathrm{J} 2- \\
242- \\
\text { SS4 }\end{array}$ & M39 & $\begin{array}{l}<0 . \\
01\end{array}$ & $\begin{array}{l}<0 . \\
01\end{array}$ & $\begin{array}{l}0 . \\
10\end{array}$ & $\begin{array}{l}0 . \\
10\end{array}$ & 0.90 & $\begin{array}{l}0 . \\
10\end{array}$ & 0.23 & $\begin{array}{l}0 . \\
20\end{array}$ & $\overline{-} \bar{s} 44$ & $\begin{array}{l}0 . \\
31\end{array}$ & -1.98 & $\begin{array}{l}0 . \\
59\end{array}$ & $\begin{array}{l}0 . \\
34\end{array}$ \\
\hline $\begin{array}{l}\text { J2- } \\
308- \\
\text { SS1 }\end{array}$ & M39 & $\begin{array}{l}0.0 \\
1\end{array}$ & $\begin{array}{l}<0 . \\
01\end{array}$ & $\begin{array}{l}0 . \\
11\end{array}$ & $\begin{array}{l}0 . \\
05\end{array}$ & 0.88 & $\begin{array}{l}0 . \\
05\end{array}$ & 0.61 & $\begin{array}{l}0 . \\
13\end{array}$ & $\overline{0} .85$ & $\begin{array}{l}0 . \\
24\end{array}$ & -2.29 & $\begin{array}{l}0 . \\
65\end{array}$ & $\begin{array}{l}0 . \\
24\end{array}$ \\
\hline \multicolumn{15}{|c|}{ Pele's Pit, Spillway area } \\
\hline $\begin{array}{l}\text { J2- } \\
245- \\
\text { SS5 }\end{array}$ & M34 & $\begin{array}{l}<0 . \\
01\end{array}$ & $\begin{array}{l}<0 . \\
01\end{array}$ & $\begin{array}{l}0 . \\
15\end{array}$ & $\begin{array}{l}0 . \\
11\end{array}$ & 0.84 & $\begin{array}{l}0 . \\
11\end{array}$ & 0.28 & $\begin{array}{l}0 . \\
20\end{array}$ & $\overline{0} .65$ & $\begin{array}{l}0 . \\
36\end{array}$ & -2.50 & $\begin{array}{l}0 . \\
57\end{array}$ & $\begin{array}{l}0 . \\
17\end{array}$ \\
\hline $\begin{array}{l}\text { J2- } \\
308- \\
\text { SS2 }\end{array}$ & M34 & $\begin{array}{l}<0 . \\
01\end{array}$ & $\begin{array}{l}<0 . \\
01\end{array}$ & $\begin{array}{l}0 . \\
27\end{array}$ & $\begin{array}{l}0 . \\
17\end{array}$ & 0.73 & $\begin{array}{l}0 . \\
17\end{array}$ & $\overline{0} .66$ & $\begin{array}{l}0 . \\
13\end{array}$ & $\overline{1.63}$ & $\begin{array}{l}0 . \\
85\end{array}$ & -3.55 & $\begin{array}{l}0 . \\
95\end{array}$ & $\begin{array}{l}0 . \\
00\end{array}$ \\
\hline $\begin{array}{l}\mathrm{J} 2- \\
314- \\
\text { SSA } \\
\text { /B }\end{array}$ & $\begin{array}{l}\text { M34 } \\
\text { /38 }\end{array}$ & 0.0 & $\begin{array}{l}<0 . \\
01\end{array}$ & $\begin{array}{l}0 . \\
09\end{array}$ & $\begin{array}{l}0 . \\
07\end{array}$ & 0.91 & $\begin{array}{l}0 . \\
07\end{array}$ & 0.16 & $\begin{array}{l}0 . \\
13\end{array}$ & $\overline{-} 0.03$ & $\begin{array}{l}0 . \\
25\end{array}$ & -1.92 & $\begin{array}{l}0 . \\
68\end{array}$ & $\begin{array}{l}0 . \\
36\end{array}$ \\
\hline \multicolumn{15}{|c|}{ Lohiau area } \\
\hline $\begin{array}{l}\overline{J 2-} \\
311- \\
\text { SS1 }\end{array}$ & M2 & $\begin{array}{l}0.0 \\
1\end{array}$ & $\begin{array}{l}<0 . \\
01\end{array}$ & $\begin{array}{l}0 . \\
08\end{array}$ & $\begin{array}{l}0 . \\
08\end{array}$ & 0.91 & $\begin{array}{l}0 . \\
08\end{array}$ & 0.98 & $\begin{array}{l}0 . \\
13\end{array}$ & $\overline{1.20}$ & $\begin{array}{l}0 . \\
26\end{array}$ & -2.34 & $\begin{array}{l}0 . \\
32\end{array}$ & $\begin{array}{l}0 . \\
22\end{array}$ \\
\hline $\begin{array}{l}\mathrm{J} 2- \\
242- \\
\text { SS2 }\end{array}$ & M5 & $\begin{array}{l}<0 . \\
01\end{array}$ & $\begin{array}{l}<0 . \\
01\end{array}$ & $\begin{array}{l}0 . \\
10\end{array}$ & $\begin{array}{l}0 . \\
12\end{array}$ & 0.90 & $\begin{array}{l}0 . \\
12\end{array}$ & 0.41 & $\begin{array}{l}0 . \\
13\end{array}$ & $\overline{-}-58$ & $\begin{array}{l}0 . \\
27\end{array}$ & -1.76 & $\begin{array}{l}0 . \\
42\end{array}$ & $\begin{array}{l}0 . \\
41\end{array}$ \\
\hline $\begin{array}{l}\text { J2- } \\
245- \\
\text { SS3 }\end{array}$ & M5 & $\begin{array}{l}<0 . \\
01\end{array}$ & $\begin{array}{l}<0 . \\
01\end{array}$ & $\begin{array}{l}0 . \\
11\end{array}$ & $\begin{array}{l}0 . \\
14\end{array}$ & 0.88 & $\begin{array}{l}0 . \\
14\end{array}$ & $\overline{0} .75$ & $\begin{array}{l}0 . \\
20\end{array}$ & $\overline{1.04}$ & $\begin{array}{l}0 . \\
42\end{array}$ & -2.20 & $\begin{array}{l}0 . \\
52\end{array}$ & $\begin{array}{l}0 . \\
27\end{array}$ \\
\hline $\begin{array}{l}\text { J2- } \\
310- \\
\text { SS2 }\end{array}$ & M5 & $\begin{array}{l}<0 . \\
01\end{array}$ & $\begin{array}{l}<0 . \\
01\end{array}$ & $\begin{array}{l}0 . \\
11\end{array}$ & $\begin{array}{l}0 . \\
13\end{array}$ & 0.88 & $\begin{array}{l}0 . \\
13\end{array}$ & 0.69 & $\begin{array}{l}0 . \\
13\end{array}$ & $\overline{-} 0.95$ & $\begin{array}{l}0 . \\
40\end{array}$ & -2.08 & $\begin{array}{l}0 . \\
60\end{array}$ & $\begin{array}{l}0 . \\
31\end{array}$ \\
\hline
\end{tabular}




\begin{tabular}{|l|l|l|l|l|l|l|l|l|l|l|l|l|l|l|}
\hline Pohaku area & 0.0 & 0.0 & 0. & 0. & 0.96 & 0. & - & 0. & - & 0. & -0.87 & 0. & 0. \\
\hline J2- & M57 & 0.0 & 0 & 04 & 04 & & 04 & 0.21 & 13 & 0.20 & 13 & & 19 & 71 \\
\hline SS1 & & 0 & 0
\end{tabular}

(a) XGe Bas, XGe Amo, XGe FeOOH: fraction of Ge hosted in basalt, amorphous silica and Fe-oxyhydroxide respectiviely

(b) $\mathrm{Ge}$ isotope composition of bulk Fe-rich deposit, from Table 2

(c) Ge isotope fractionation factor: $\Delta^{4 / 70} \mathrm{Ge}_{\text {(FeOOH-Fluid) }}=8^{4 / 70} \mathrm{GeFeOOH}-8^{4 / 70} \mathrm{Ge}_{\text {Fluid }}$; with fluid values from Table 1

(d) fraction of $\mathrm{Ge}$ adsorbed onto Fe-oxyhydroxide, considering an equilibrium $\mathrm{Ge}$ isotope fractionation factor obetween $\mathrm{FeOOH}$ and Fluid of 0.997. $\mathrm{f}_{\text {ads }}=1-$ $\Delta^{4 / 70} \mathrm{Ge}_{\text {(FeOOH-Fluid) }} /\left(1000^{*} \mathrm{Ln}\left(\mathrm{o}^{\mathrm{k}}\right)\right.$

2sd: 2 standard deviation determined through error propagation (Monte Carlo method)

Table 6: Global Si and Ge fluxes in modern ocean, and their Ge/Si and Ge isotope signatures.

\begin{tabular}{|c|c|c|c|c|c|c|c|c|c|}
\hline \multirow[t]{2}{*}{$\begin{array}{l}\text { Sources/Sin } \\
\text { ks }\end{array}$} & $\begin{array}{l}\mathrm{Si} \\
\text { Flux }\end{array}$ & err & $\begin{array}{l}\text { Ge } \\
\text { Flux }\end{array}$ & err & $\mathrm{Ge} / \mathrm{Si}$ & err & $8^{4 / 70} \mathrm{Ge}$ & err & $\begin{array}{l}\Delta^{4 / 70} G \\
e^{\text {sw. }}\end{array}$ \\
\hline & $\begin{array}{l}10^{12} \\
\mathrm{~mol} / \mathrm{y}\end{array}$ & & $\begin{array}{l}\left(10^{6}\right. \\
\mathrm{mol} / \mathrm{y}\end{array}$ & & ( $\mu \mathrm{mol} / \mathrm{mo}$ & & $\begin{array}{l}\text { NIST3120 } \\
a\end{array}$ & & $\begin{array}{l}\text { Sink } \\
\text { (b) }\end{array}$ \\
\hline \multicolumn{10}{|l|}{ Input } \\
\hline $\begin{array}{l}\text { Riverine } \\
\text { (case 1) }\end{array}$ & 5.60 & $\begin{array}{l}0.6 \\
0\end{array}$ & 3.02 & $\begin{array}{l}0.6 \\
0\end{array}$ & 0.54 & $\begin{array}{l}0.1 \\
0\end{array}$ & 0.56 & $\begin{array}{l}0.2 \\
0\end{array}$ & \\
\hline $\begin{array}{l}\text { Riverine } \\
\text { (case 2) }\end{array}$ & 5.60 & $\begin{array}{l}0.6 \\
0\end{array}$ & 3.02 & $\begin{array}{l}0.6 \\
0\end{array}$ & 0.54 & $\begin{array}{l}0.1 \\
0\end{array}$ & 3.00 & $\begin{array}{l}0.2 \\
0\end{array}$ & \\
\hline Eolian & 0.50 & $\begin{array}{l}0.5 \\
0\end{array}$ & 0.27 & $\begin{array}{l}0.3 \\
0\end{array}$ & 0.54 & & 0.56 & $\begin{array}{l}0.2 \\
0\end{array}$ & \\
\hline $\begin{array}{l}\text { Hydrotherma } \\
\text { la }\end{array}$ & 0.55 & $\begin{array}{l}0.1 \\
0\end{array}$ & 6.05 & $\begin{array}{l}1.0 \\
8\end{array}$ & 11.00 & $\begin{array}{l}3.0 \\
0\end{array}$ & 1.55 & $\begin{array}{l}0.3 \\
6\end{array}$ & \\
\hline $\begin{array}{l}\text { LT basalt }+ \\
\text { flanks }\end{array}$ & 0.82 & $\begin{array}{l}0.4 \\
1\end{array}$ & 1.10 & $\begin{array}{l}0.5 \\
5\end{array}$ & 1.34 & $\begin{array}{l}0.6 \\
7\end{array}$ & 1.20 & $\begin{array}{l}0.5 \\
0\end{array}$ & \\
\hline \multicolumn{10}{|c|}{ Output } \\
\hline $\begin{array}{l}\text { Opal burial } \\
\text { (a) }\end{array}$ & 7.47 & $\begin{array}{l}0.8 \\
9\end{array}$ & 5.23 & $\begin{array}{l}0.6 \\
3\end{array}$ & 0.70 & $\begin{array}{l}0.1 \\
0\end{array}$ & 3.00 & $\begin{array}{l}0.2 \\
0\end{array}$ & \\
\hline $\begin{array}{l}\text { Non-opal } \\
\text { sink (case 1) }\end{array}$ & 0.00 & & 5.22 & $\begin{array}{l}1.5 \\
2\end{array}$ & & & -0.58 & $\begin{array}{l}0.6 \\
0\end{array}$ & 3.58 \\
\hline $\begin{array}{l}\text { Non-opal } \\
\text { sink (case 2) }\end{array}$ & 0.00 & & 5.22 & $\begin{array}{l}1.5 \\
2\end{array}$ & & & 0.87 & $\begin{array}{l}0.4 \\
0\end{array}$ & 2.13 \\
\hline
\end{tabular}

See text for discussion and appropriate references relative to the assigned values "err" corresponds to the estimated uncertainty of both input or output values used in the box model

(a) Opal burial sink is determined by assuming no $\mathrm{Ge} / \mathrm{Si}$ and $\mathrm{Ge}$ isotope fractionation relative to seawater 
case 1 assumes a global riverine flux with $\mathrm{Ge}$ isotope composition identical to bulk crust values

case 2 assumes a global riverine flux with Ge isotope composition identical to seawater

(b) Signature of the missing sink for the case 1 and case 2 corresponding to the difference between seawater and Non-opal sink Ge composition 


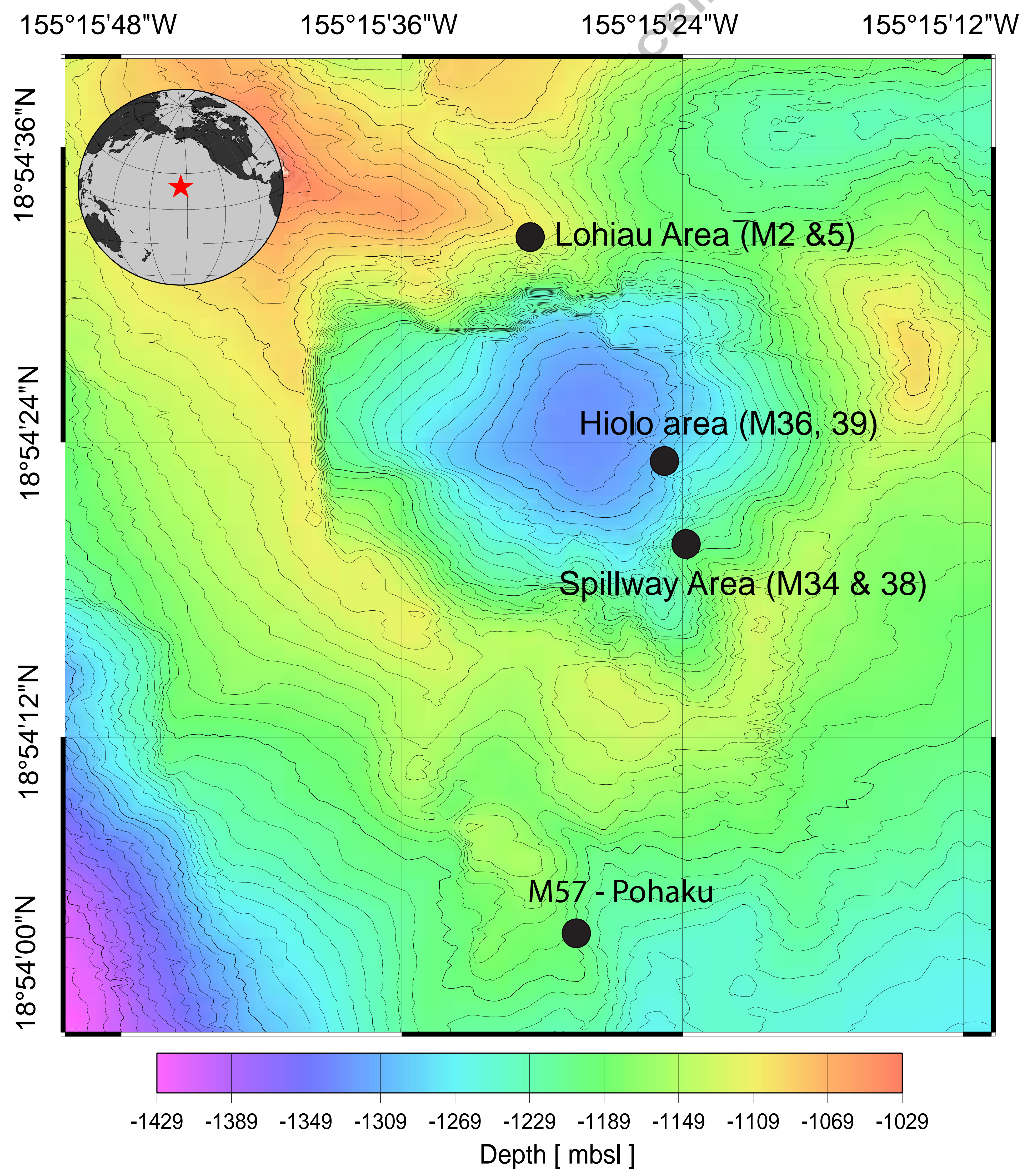




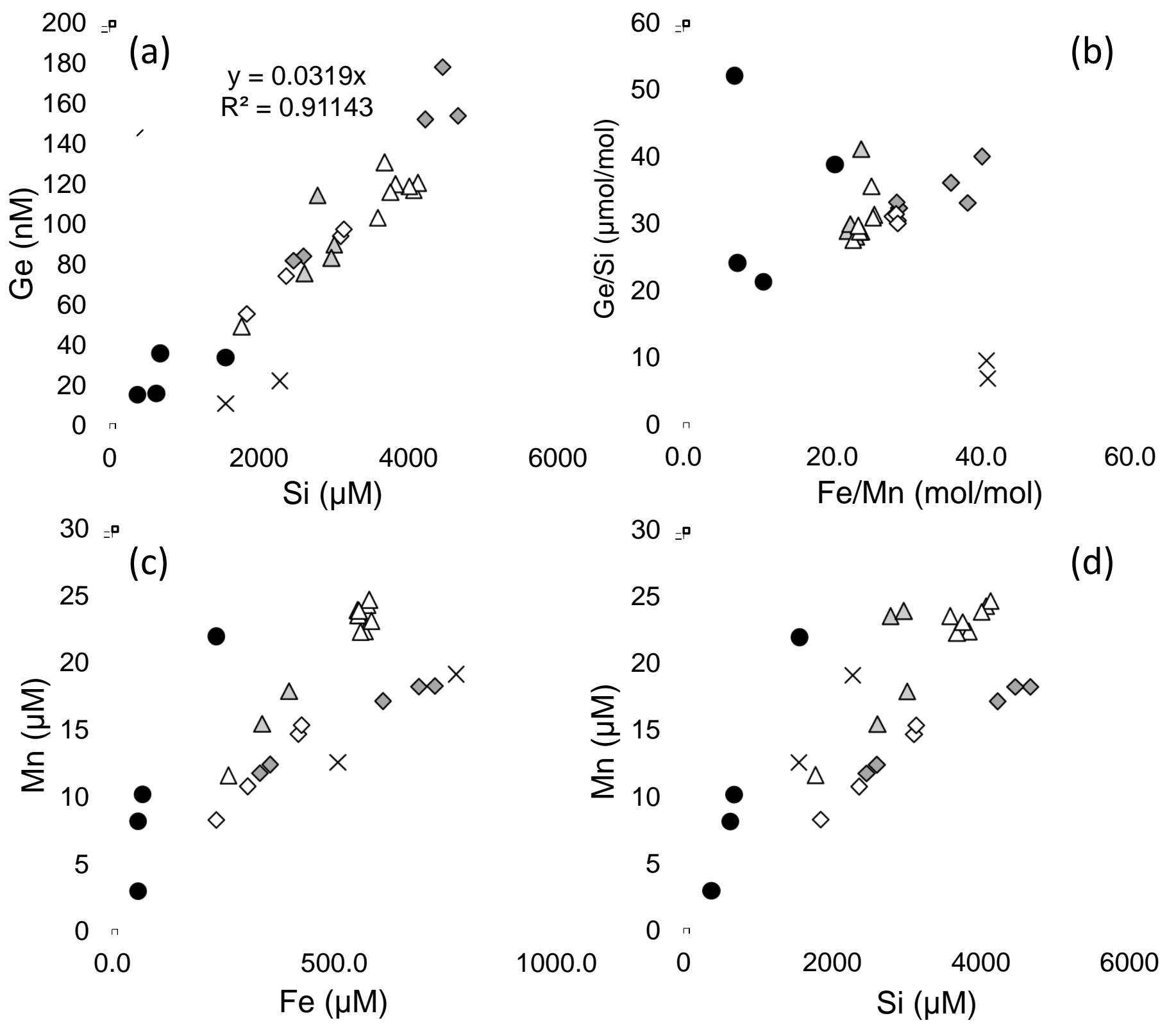

Spillway area

Hiolo area

Lohiau

Pohaku

M34 ${ }^{\triangleleft}$ M38 $\triangle M 36{ }^{\star}$ M39

M5

X M57

Figure 2 


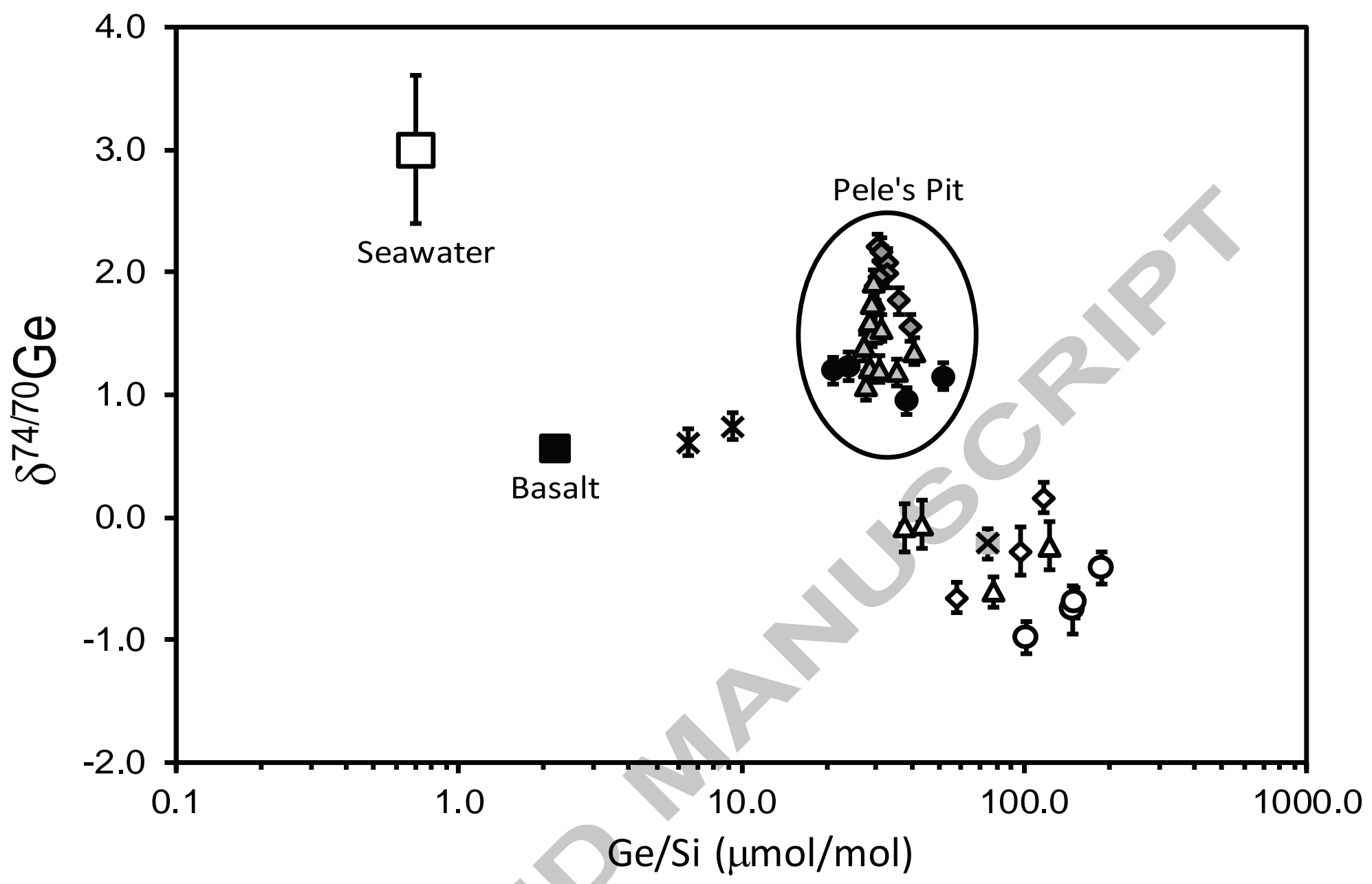

$\begin{array}{ll}\diamond \text { Spillway area (fluids) } & \text { OLohiau area (fluids) } \\ \diamond \text { Spillway Area (Fe-rich deposits) } & \text { OLohiau Area (Fe-rich deposits) } \\ \Delta \text { Hiolo area (fluids) } & \text { xPohaku area (fluids) } \\ \Delta \text { Hiolo area (Fe-rich deposits) } & \times \text { Pohaku area (Fe-rich deposits) } \\ \square \text { Basalt } & \square \text { Seawater }\end{array}$




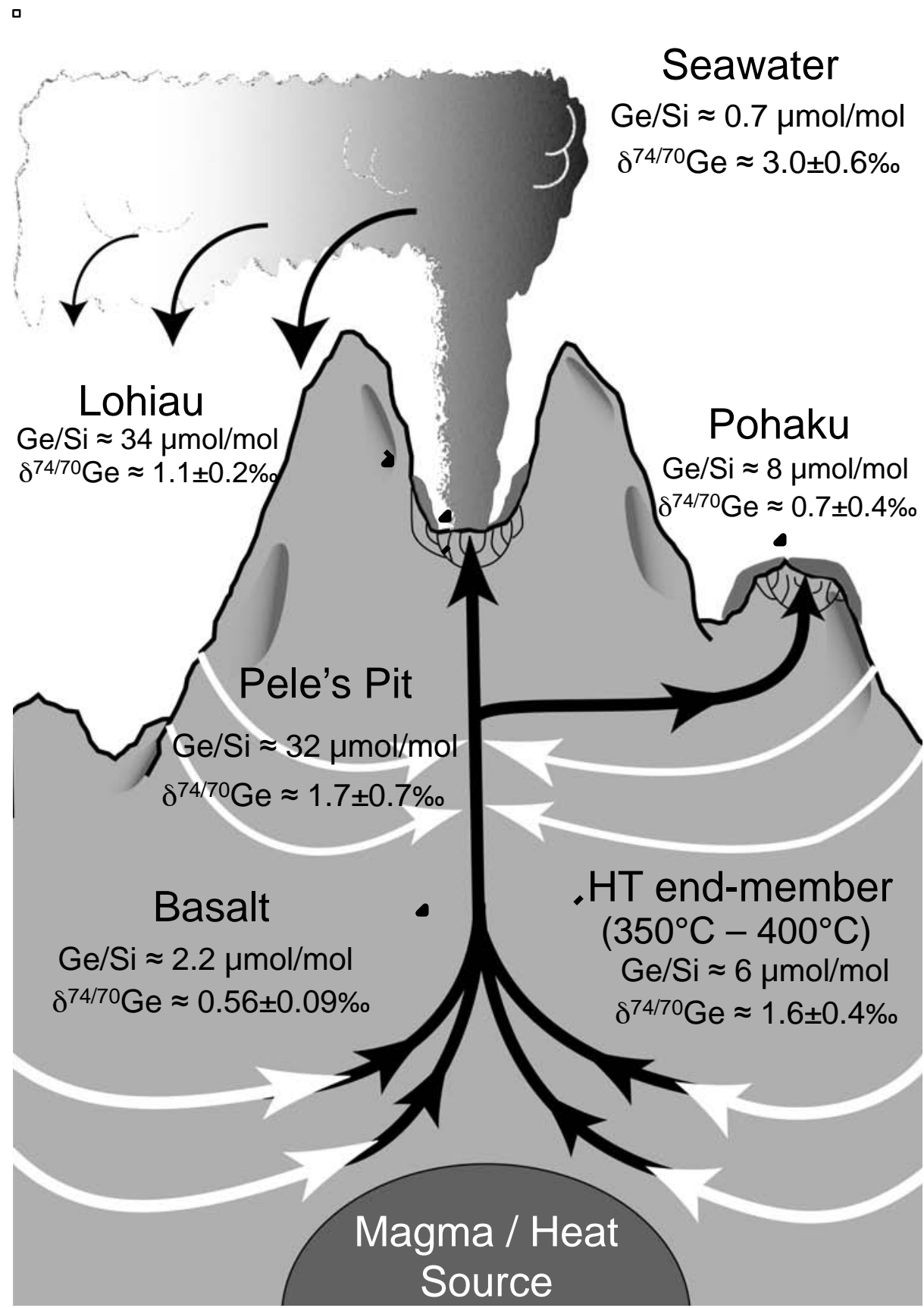

Figure 4 